\title{
Selection of Optimal Tunnel Route and Tunneling Method based on AHP Technique.
}

\author{
Case Study - Broadlands Hydropower Project
}

\author{
M.N.Dilhani, S.M.M.Subasinghe, E.A.R.M.Edirisinghe, \\ M.N.C. Samarawickrama and K. Laksiri
}

\begin{abstract}
Selection of optimal tunnel route and tunnelling methods for head raise tunnel of a hydropower project is one of the most critical and complicated steps in its design stage. Since factors involved are highly diversified, the decision making process is quite complicated. In this study, the Analytical Hierarchy Process (AHP), a multi criterion decision making tool was employed to establish the optimal tunnel route and the most appropriate tunnelling method for the established optimal tunnel route. The optimal tunnel route was established by evaluating two tunnel route options with ten factor criterion. Four tunnelling alternatives were evaluated against relevant ten factor criterion in selecting the most suitable tunnelling method for the selected optimal tunnel route. Criterion were limited to geotechnical, geological, geomorphological, safety, technical, economical and socioenvironmental aspects. Analysis reveals that, route B, which is having the overall composite weight of $0.513(51.30 \%)$ is the optimal tunnel route and combination of Drill \& Blast method (section III of route B) and New Austrian Tunnelling Method (sections I and II of route B) is the most appropriate tunnelling criteria along the selected tunnel route.
\end{abstract}

Keywords: Analytical Hierarchy Process, Rock mass classification systems, Rock slope stability analysis, Drill \& Blast method, New Austrian Tunnelling method

\section{Introduction}

Route selection is the critical initial step in the process of design and construction of a tunnel. In planning a suitable tunnel route, the geological, geotechnical, hydrological, hydro geological, socio-environmental, economic and technical factors need to be taken into consideration. However, these factors are heavily diversified and hence the planning and decision making process becomes complicated. Internationally, it has been practiced and proven that Analytical Hierarchy Process (AHP) can be used effectively in finding solutions to such complicated decision making problems and even the adoptability to tunneling industry has been proven [1].

Similarly, selection of tunneling method is also critical and is a complex decision making process in tunnel engineering. The selected tunneling method should ensure mine safety with least hazard levels and it should also be technically, economically and socioenvironmentally sound enough.

\subsection{Scope and Objectives of the Study}

This study was aimed at selecting the most suitable tunnel route and tunneling method for BHP.
This study is focused on a part of the head raise tunnel of the Broadlands Hydropower Project (BHP), which is one of the major ongoing hydropower construction projects in Sri Lanka. It is located in the Central Highlands; approximately ninety kilometers east of Colombo city. This will be the last hydropower project of the Kelani River basin. The considered part of the tunnel has two proposed route alternatives, Route A and Route $\mathrm{B}$ and the lengths are $1.2 \mathrm{~km}$ and $1.5 \mathrm{~km}$ respectively. The specific objectives of the study are to,

Eng. M.N. Dilhani, BTech (Eng) (OUSL), AMIE(SL), NDES (IET Katunayake), Civil Superintendent, Ceylon Electricity Board, Colombo 02.

Eng. S.M.M. Subasinghe, BTech (Eng) (OUSL), AMIE(SL), NDES (IET Katunayake), Instructor, Department of Technical Education and Training, Colombo 10.

E.A.R.M. Edirisinghe, NDES (IET Katunayake), Technical Officer, Engineering Organization (WP), Colombo 07.

Eng. M.N.C. Samarawickrama, C. Eng., MIE(SL), MGS (SL), B.Sc. Eng. Hons.(Moratuwa), M.Sc. (Peradeniya), MBA (Moratuwa), Senior Lecturer in Civil Engineering, Department of Civil Engineering, The Open University of Sri Lanka. Email:mahesh.samarawickrama@gmail.com

Eng. (Dr.) K. Laksiri, BSc Eng. (Hons), MSc, PhD, FIESL, FICE, MASCE, MASME, MIET, C. Eng. Int. PE(SL), Project Director, Broadlands Hydropower Project, Ceylon Electricity Board, Colombo 02. 
1. Carry out a comprehensive engineering geological study and a cost analysis for the proposed tunnel routes.

2. Recommend the most suitable tunnel route using Analytical Hierarchy Process (AHP).

3. Recommend the most appropriate tunnelling technique for the selected tunnel route using AHP method.

\section{Methodology}

The following methodology was adopted in order to achieve the above mentioned objectives.

\subsection{Data Collection}

Data collection was performed in order to obtain maximum amount of relevant engineering geological information of the area such as rock mass characteristics and ground water conditions [2] as the accuracy of the decision totally depends on the reliability and adequacy of the data collected from both literature and field.

Number of field data collections were performed to collect necessary data using exposed rock outcrops.

\subsubsection{Desk Study}

Initial study was performed on the case histories in applying AHP for projects of similar nature [1], [3], [4] and [5]. Geology and the Geomorphology of the area was studied using 1:50,000 scale topography and geology maps with contours at $10 \mathrm{~m}$ intervals prepared by the Survey Department of Sri Lanka and the geological maps of the study area developed by JICA at the feasibility study stage of the project [6].

\subsubsection{Field Data Collection}

Rock texture, discontinuity orientations and their conditions were obtained from previously carried out borehole logs, rock outcrops at the tunnel trace as well as from the walls of partly excavated adit of tunnel route $\mathrm{A}$.

Considerable amount of socio-environmental information were gathered through the discussions made with the experts engaged in the project and with the village community.

\subsection{Engineering Geological Assessment}

Comprehensive Engineering Geological Assessment for the area was carried out to study the engineering geological behaviour of the two tunnel routes. The assessment was initiated with the development of engineering geological maps for the particular area and subsequently the longitudinal cross sections along the tunnel routes. This was further extended by performing rock mass classification and stability analysis against possible rock slope failures along tunnel walls. The results are summarized in Annexure 01.

\subsubsection{Rock Mass Classification.}

The rock mass classification was performed to examine the properties of the rock mass in a very systematic manner and classify rock mass in to different rock classes. This can effectively combine the findings from observations, experience and engineering judgment in providing a quantitative assessment of rock mass conditions. The rock mass classification was performed along two tunnel routes using Rock Mass Rating (RMR) [7] and Rock Quality Index (Q method) [8] to examine the quality of the surrounding rock masses in a systematic manner and to classify rock mass into different rock classes. Sample calculation has been included in Annexure 02 and the results are summarized in Tables 01 to 04 .

\section{Rock Mass Rating (RMR)}

Rock mass along each tunnel route was sectioned, based on the engineering geological characteristics and then a rock mass condition assessment was performed for each section using rock mass rating system for parameters given below;

I. Uniaxial compressive strength of rock material.

II. Rock Quality Designation (RQD).

III. Spacing of discontinuities.

IV. Condition of discontinuities.

V. Groundwater conditions.

VI. Orientation of discontinuities.

In this system, rocks are classified as;

Class I - $\quad$ Very good rock, RMR 81-100

Class II - Good rock, RMR 61-80

Class III- $\quad$ Fair rock, RMR 41-60

Class IV- $\quad$ Poor rock, RMR 21-40

Class V - Very poor rock, RMR $<20$

Overall $\mathrm{RMR}=\Sigma\left(\mathrm{L}_{\mathrm{i}} \times \mathrm{RMR}_{\mathrm{i}}\right) / \mathrm{L}$

Where;

$\mathrm{L}_{\mathrm{i}} \quad$-Length of the specific tunnel section

$\mathrm{RMR}_{\mathrm{i}} \quad-\mathrm{RMR}$ value of the specific section

$\mathrm{L} \quad$-Total length of the tunnel route 


\section{Rock Tunneling Quality Index (Q Method)}

The $Q$ index is used to classify rock mass around an underground opening and is used as a guide for the design of the tunnel support requirements [8]. The numerical value of the index $Q$ varies on a logarithmic scale from the value 0.001 to a maximum value of 1,000 . This is defined as;

$Q=\frac{R Q D}{J_{n}} \times \frac{J_{r}}{J_{a}} \times \frac{J_{w}}{S R F}$

Where,

$\begin{array}{lll}\text { RQD } & - & \text { Rock Quality Designation } \\ \mathrm{J}_{\mathrm{n}} & - & \text { Joint set number } \\ \mathrm{J}_{\mathrm{r}} & - & \text { Joint roughness number } \\ \mathrm{J}_{\mathrm{a}} & - & \text { Joint alteration number } \\ \mathrm{J}_{\mathrm{W}} & - & \text { Joint water reduction factor } \\ \mathrm{SRF} & - & \text { Stress reduction factor }\end{array}$

In this system, rocks are classified as;

Class A - Exceptionally good rock- Q 400-1000

Extremely good rock- Q 100-400

Very good rock-Q 40-100

Class B - Good rock, Q 10-40

Class C - Fair rock, Q 04-10

Class D - Poor rock, Q 01-04

Class E - Very poor rock, Q 0.1-01

Class F - Extremely poor, Q 0.01-0.1

Class G - Exceptionally poor, Q 0.001-.01

Similar to RMR, overall $Q$ for each tunnel route was estimated as given below

$$
\text { Overall } \mathrm{Q}=\Sigma\left(\mathrm{L}_{\mathrm{i}} \times \mathrm{Q}_{\mathrm{i}}\right) / \mathrm{L}
$$

Where;

$\mathrm{L}_{\mathrm{i}} \quad$ - Length of the specific tunnel section

$Q_{i} \quad-Q$ value of the specific section

$\mathrm{L} \quad$ - Total length of the tunnel route

\subsubsection{Rock Wedge Stability Analysis}

Failures along discontinuities, such as faults, bedding planes and joints are common during underground excavations in hard rock masses [9]. In this regard, stereonet analysis, which is a graphical technique [9], was performed considering only the major joint sets in the particular sections. Section 3.5 presents the results of the rock wedge stability analysis.

\subsubsection{Tunnelling Cost Analysis}

The tunnel construction cost per meter run of the two route options were evaluated for the purpose of tunnel construction cost comparison. The construction cost includes excavation and supporting cost. Data for cost items were obtained from Kukuleganga and Upper Kothmale Hydropower Projects in Sri
Lanka [10]. The results are summarized in Table 06 and 07 .

\subsection{Applying Analytic Hierarchy Process (AHP)}

There are many factors involved in the selection of tunnel route and tunneling method. Therefore, a multiple factor decision making approach was required for this analysis. In this regard, the AHP method, which was introduced by Prof. Thomas L. Satty in 1980 was adopted [11].

After identifying the problem, selection of criterion was carried out based on factors which are explicit in the problem stated.

Then the possible alternative solutions for the problem were identified and the solution process was proceeded to select the most appropriate alternative [11]. Figure 01 shows the structure of hierarchy for above three steps.

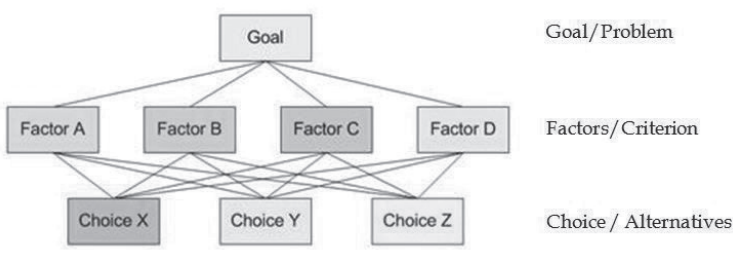

\section{Figure 01 - Structure of Hierarchy for AHP}

In selecting optimal tunnel route, the identified main criterion were: surrounding rock type, rock slope stability, tunnel overburden, tunnel geometry, geomorphology, tunnel construction safety, socio-environmental impacts, tunneling cost (drilling, blasting, supporting etc), construction duration and length of the tunnel route. The alternatives were Route A and Route B.

To identify the main criterion to be incorporated in the AHP model, the importance of above mentioned factors were assessed. For this purpose, a survey was conducted among 23 experts from different functional levels in local tunneling industry.

In selecting the suitable tunneling method, the identified factors were rock mass properties, tunnel geometry, tunnel overburden, ability of mechanization, groundwater level and expected water inflow, tunnel construction safety, socio-environmental impacts, surface disturbances, time/cost considerations and local experience [1]. These factors were evaluated over three alternative tunneling methods namely drill and blast (D \& B), cut and 
cover ( $C$ \& $C)$, and New Austrian Tunneling Method (NATM). The Tunnel Boring Machine (TBM) option was not considered since it is uneconomical for short length tunnels.

For the assessment, a questionnaire with a fivepoint scale for each of the criterion had been prepared. The respondents were asked to rate each factor according to a five-point scale, based on the priority that should be placed for each factor.

A weight had been assigned to each alternative through a pair-wise comparison based on the studied geological, geotechnical and other relevant conditions. The pair-wise comparison matrices were made with the aid of the scale of relative importance defined by Satty, 2008 [11]. The relative priorities of alternatives were obtained by this comparison and hence the relative suitability of the available alternatives to serve the objective was defined.

\section{Specimen calculation}

Step 1:

Pair-wise comparison of route A and B against "Surrounding rock conditions"

According to rock mass classification, the average importance of route $\mathbf{A}$ over route $\mathbf{B}$ in terms RMR and $Q$ values is nearly $25 \%$. It is almost $1 / 4^{\text {th }}$ of the scale. Therefore, surrounding rock type of route $\mathbf{A}$ is weakly important than route $\mathbf{B}$. Referring to the table of relative importance defined by Satty, the intensity of importance is 3. This is marked on the Satty's scale of relative importance as follows.

\begin{tabular}{|c|c|c|c|c|c|}
\hline \multirow[b]{2}{*}{ Factor } & \multicolumn{4}{|c|}{ Factor weighting score } & \multirow[b]{2}{*}{ Factor } \\
\hline & $\begin{array}{l}\text { More importance } \\
\text { than B }\end{array}$ & Equal & Less impe & lance than & \\
\hline \multirow{3}{*}{ Rowte A } & \multicolumn{4}{|c|}{ 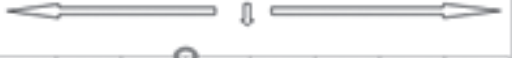 } & \multirow{3}{*}{ Rowte B } \\
\hline & $\mathrm{T}$ & $\mathrm{T}$ & 1 & $T$ & \\
\hline & 5 & 1 & 3 & 7 & \\
\hline
\end{tabular}

Step 2:

Build up pair wise comparison matrix

According to the rules of AHP, the built up pair wise comparison matrix is as follows.

\begin{tabular}{|l|cc|}
\hline Surrounding rock type & Route A & Route B \\
\hline Route A & 1 & 3 \\
Route B & $1 / 3$ & 1 \\
\hline
\end{tabular}

The normalized principal Eigen vector (also called priority vector) (w) is calculated and given by; $w=\left[\begin{array}{l}0.75 \\ 0.25\end{array}\right]$

The priority vector provides relative weights of the two route alternatives against "surrounding rock conditions". The weight of Route A is 75\% and the weight of route $\mathbf{B}$ is $25 \%$.

Step 3:

Check for consistency

When many pair wise comparisons are performed, some inconsistencies may typically arise. Therefore consistency of judgment is checked as follows.

$\mathrm{CI}=\frac{\lambda \max -\mathrm{n}}{\mathrm{n}-1}$

Where $\mathbf{C I}$ is the consistency index, $\boldsymbol{n}$ is the size of the matrix and $\boldsymbol{\lambda}_{\max }$ is the principal Eigen value.

For this specimen calculation,

$$
\begin{gathered}
n=2 \\
\lambda_{\operatorname{Max}}=4 / 3 \times 0.75+4 \times 0.25=2.0 \\
\text { Hence, } \mathrm{CI}=(2-2) /(2-1)=0
\end{gathered}
$$

According to AHP theory, if $\lambda_{\operatorname{Max}}=n$, then the judgments have turned out to be consistent.

The composite weight of each alternative against all selected criterion can be determined using the decision matrix. Hence the relative suitability of the available alternatives is defined to serve for the objective.

The AHP method was applied twice separately to serve two initial objectives. First, to select the optimal tunnel route and then to select the most suitable tunneling method. The composite weights derived are summarized in Tables 08, 09 and 10 .

\section{Engineering Geological and Cost Assessment \\ 3.1 Geographical Condition of the Area}

The Broadlands Hydropower Project area is located in the central highlands; approximately ninety kilometres east of Colombo city. The area is widely underlain by Precambrian Gneiss. Two tributaries of the Kelani River, Maskeli Oya and Kehelgamu Oya join each other immediately downstream of the proposed dam site [6].

Kelani River forms a deep valley at the project area. The river bed elevation in this area is approximately $100 \mathrm{~m}$ from mean sea level. The 
slopes on both banks rise to ridges of more than 500 m elevation.

For this study, only the area marked in green colour dotted line in Figure 02, which enclosed the selected tunnel route alternatives up to common main tunnel, was considered.

\subsection{Engineering Geological Mapping}

Engineering geological map of the particular site under study was developed as depicted in Figure 03 and exhibits the information of existing rock types, the arrangement of different rock beds below the ground, the details of existing structural geological features of the area and the various topographical features.

\subsection{Geological Subsurface Profiles along Tunnel Routes}

Based on the available borehole logs and geological maps, sub surface profiles along the tunnel routes were developed. However, it should be emphasized that, most of the performed boreholes were not exactly aligned on the proposed tunnel routes and hence the sub surface conditions were interpreted using the nearest borehole data to come up with most reasonable geological sub surface profiles and presented in Figures 03 and 04.

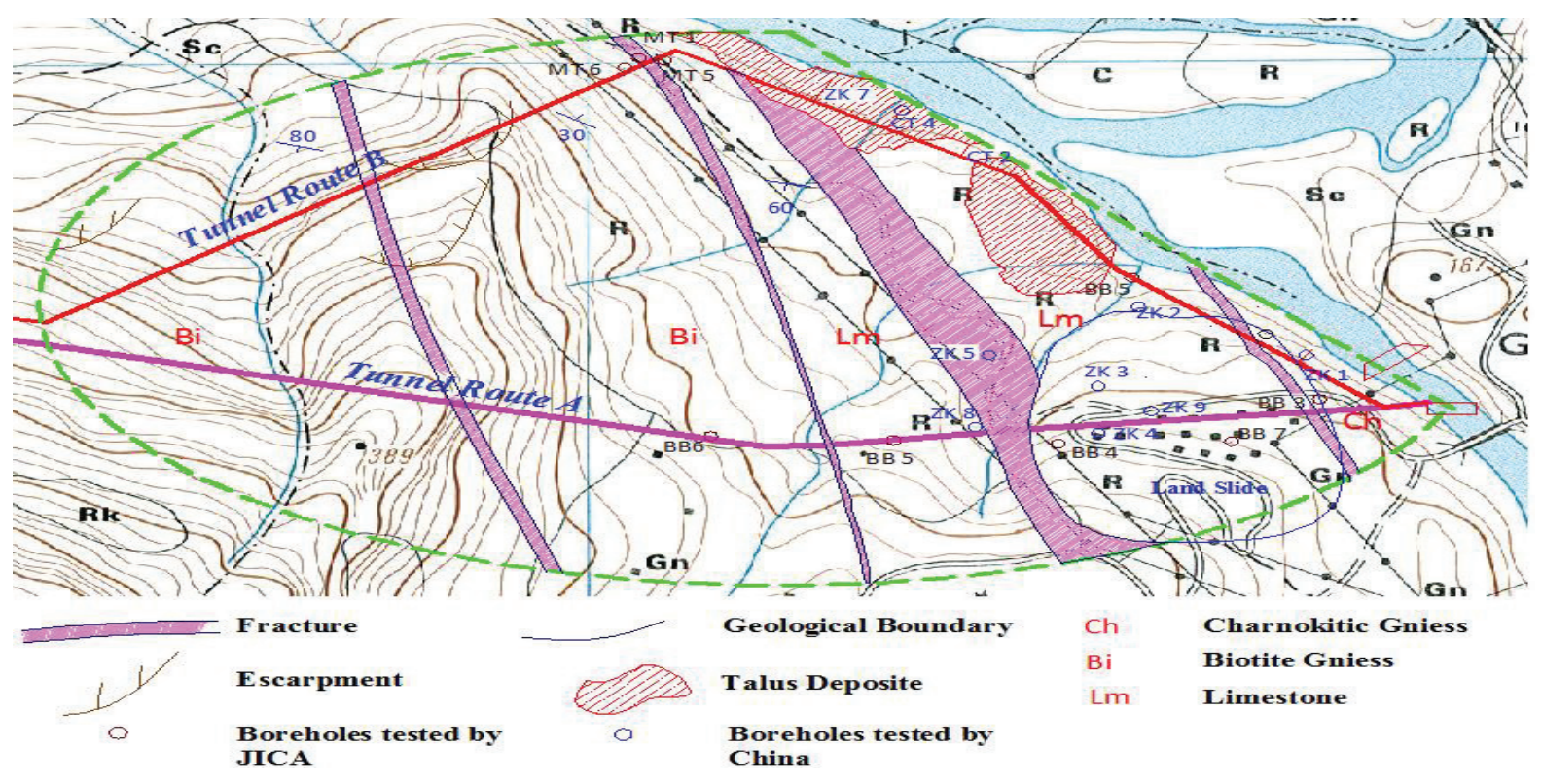

Figure 02 - Tunnel Routes A and B in area Geology Map

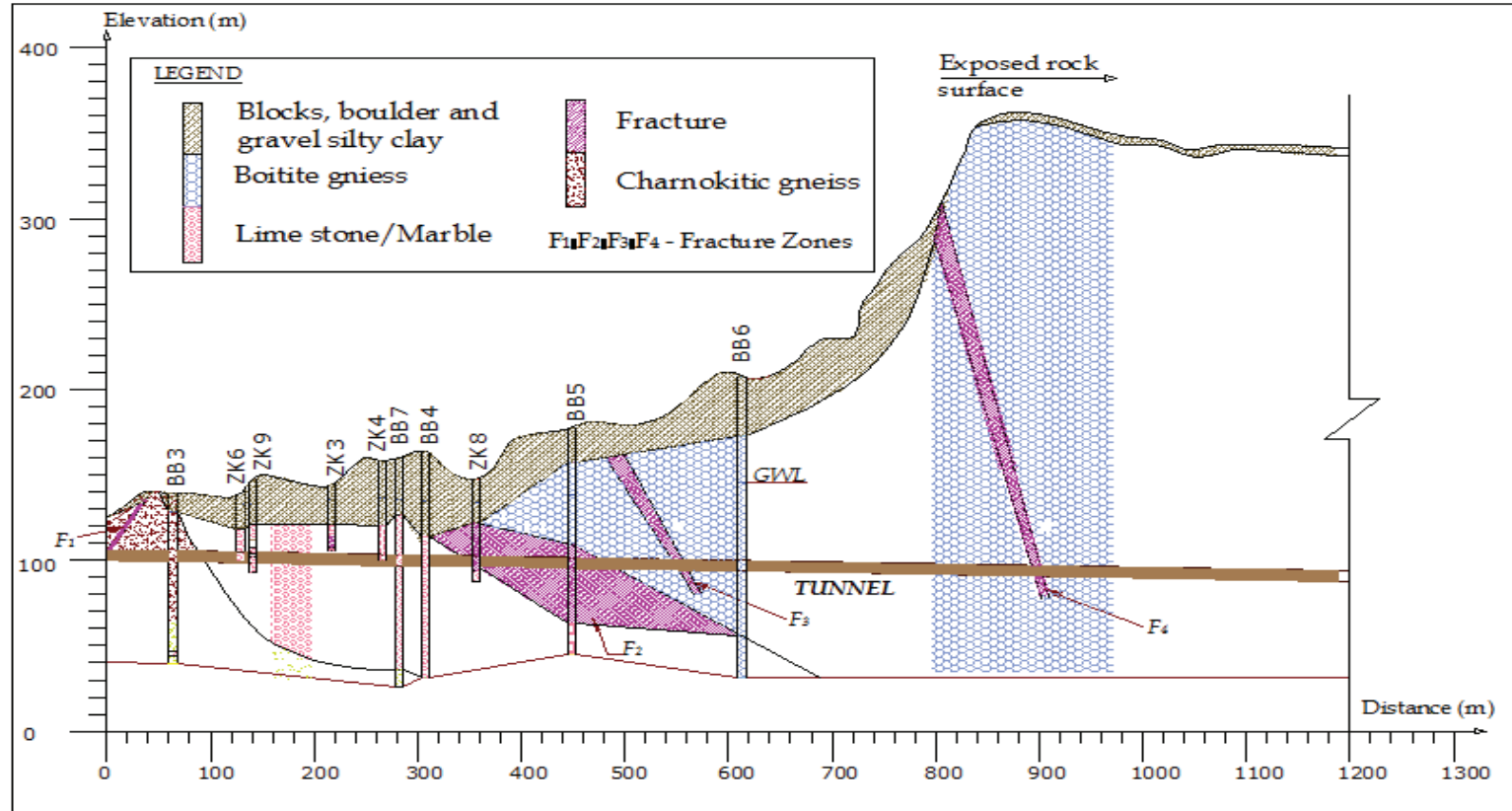

Figure 03 - Geological Sub Surface Profile along Tunnel Route A 


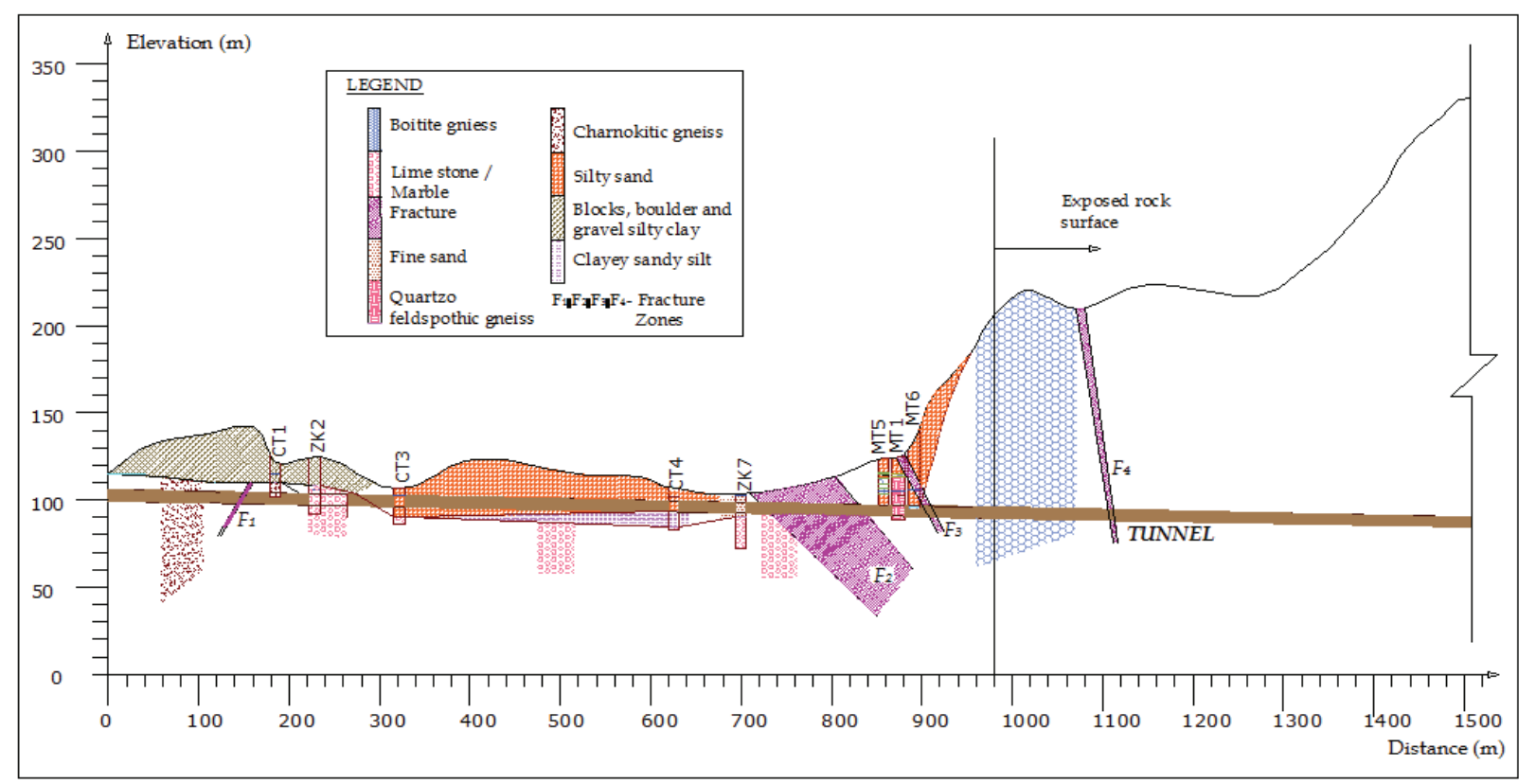

Figure 04 - Geological Sub Surface Profile along Tunnel Route B

\subsection{Results of Rock Mass Classification}

Relevant RMR and $Q$ charts are provided in Annexure 03.

Table 01 - RMR and Rock Mass Quality and Supporting System along Route A

\begin{tabular}{lccc}
\hline $\begin{array}{l}\text { Tunnel } \\
\text { section (m) }\end{array}$ & RMR & $\begin{array}{l}\text { Rock mass } \\
\text { quality }\end{array}$ & $\begin{array}{l}\text { Supporting } \\
\text { system }\end{array}$ \\
\hline $0-8$ & 44 & Fair & $1 \& 2$ \\
$8-323$ & 35 & Poor & $3 \& 4$ \\
$323-508$ & 17 & Very Poor & $5 \& 6$ \\
$508-564$ & 29 & Poor & $3 \& 4$ \\
$564-1200$ & 43 & Fair & $1 \& 2$ \\
$\begin{array}{l}\text { Overall } \\
\text { (Eqn (1)) }\end{array}$ & 38 & Poor & \\
\hline
\end{tabular}

Table 02 - RMR and Rock Mass Quality and Supporting System along Route B

\begin{tabular}{lccc}
\hline $\begin{array}{l}\text { Tunnel } \\
\text { section }(\mathrm{m})\end{array}$ & RMR & $\begin{array}{c}\text { Rock mass } \\
\text { quality }\end{array}$ & $\begin{array}{l}\text { Supporting } \\
\text { system }\end{array}$ \\
\hline $0-40$ & 41 & Fair & 1 \& 2 \\
$40-360$ & 42 & Fair & 1 \& 2 \\
$360-860$ & NA & - & - \\
$860-1500$ & 43 & Fair & 1 \& 2 \\
$\begin{array}{l}\text { Overall } \\
\text { (Eqn (1)) }\end{array}$ & 30 & Poor & \\
\hline
\end{tabular}

Legend for supporting system

1. Systematic bolts $4 \mathrm{~m}$ long, spaced $1.5-2 \mathrm{~m}$ in crown and walls with wire mesh in crown

2. $\quad 50-100 \mathrm{~mm}$ thick shotcrete in crown and 30 $\mathrm{mm}$ in walls

3. Systematic bolts $4-5 \mathrm{~m}$ long, spaced $1-1.5 \mathrm{~m}$ in crown and walls with wire mesh

4. $100-150 \mathrm{~mm}$ thick shotcrete in crown and $100 \mathrm{~mm}$ in walls
5. Systematic bolts 5-6m long, spaced 1-1.5 m in crown and walls with wire mesh

6. $150-200 \mathrm{~mm}$ thick shotcrete in crown, 150 $\mathrm{mm}$ in walls and $50 \mathrm{~mm}$ on face

Table 03 - $Q$ value, rock mass quality and supporting system along Route $A$ according to $Q$ charts

\begin{tabular}{|c|c|c|c|c|}
\hline \multirow{2}{*}{$\begin{array}{l}\text { Chainage } \\
\text { (m) }\end{array}$} & \multirow[t]{2}{*}{ Q } & \multirow{2}{*}{$\begin{array}{c}\text { Rock mass } \\
\text { quality }\end{array}$} & \multicolumn{2}{|c|}{$\begin{array}{c}\text { Supporting } \\
\text { system category }\end{array}$} \\
\hline & & & Crown & Wall \\
\hline $0-8$ & 4.750 & Fair & 1 & 1 \\
\hline $8-100$ & 3.770 & Fair & 4 & 1 \\
\hline $100-220$ & 1.430 & Poor & 4 & 4 \\
\hline $220-323$ & 0.530 & very Poor & 5 & 8 \\
\hline $323-400$ & 0.002 & $\begin{array}{l}\text { Exception- } \\
\text { ally poor }\end{array}$ & 8 & 7 \\
\hline $400-508$ & 0.067 & $\begin{array}{c}\text { Extremely } \\
\text { poor }\end{array}$ & 7 & 5 \\
\hline 508-1200 & 5.000 & Fair & 3 & 1 \\
\hline $\begin{array}{l}\text { Overall } \\
(\text { eqn (3)) }\end{array}$ & 3 & Poor & & \\
\hline
\end{tabular}

Table 04 - $Q$ value, rock mass quality and supporting system along Route $B$ according to $Q$ charts

\begin{tabular}{|c|c|c|c|c|}
\hline \multirow[t]{2}{*}{$\begin{array}{c}\text { Chainage } \\
\text { (m) }\end{array}$} & \multirow[t]{2}{*}{ Q } & \multirow[t]{2}{*}{$\begin{array}{c}\text { Rock mass } \\
\text { quality }\end{array}$} & \multicolumn{2}{|c|}{$\begin{array}{l}\text { Supporting } \\
\text { system } \\
\text { category }\end{array}$} \\
\hline & & & Crown & Wall \\
\hline $0-200$ & 0.9 & Very poor & 5 & 4 \\
\hline $200-275$ & 1.6 & Poor & 4 & 4 \\
\hline $275-860$ & 0 & \multicolumn{3}{|c|}{ Cut and cover tunnel } \\
\hline $860-1500$ & 5.6 & Fair & 3 & 1 \\
\hline $\begin{array}{l}\text { Overall } \\
(\text { eqn }(3))\end{array}$ & 3 & Poor & & \\
\hline
\end{tabular}


3.5 Stereonet Analysis Results of Rock Joints The stereonet plots as shown in Figure 05 to 07 were developed based on the major joint sets in the area, listed in Table 05. Individual plane failures are possible along all three joint sets. Out of them, most vulnerable is joint set 1 and least is joint set 3, which has the least dip. Wedge failures are possible along the combination of joint sets 1, 2 and 1, 3. The most vulnerable of them is the wedging along the intersection of joint sets 1, 2 for both routes.

Figure 05 - Stereonet Plot of Great Circles of

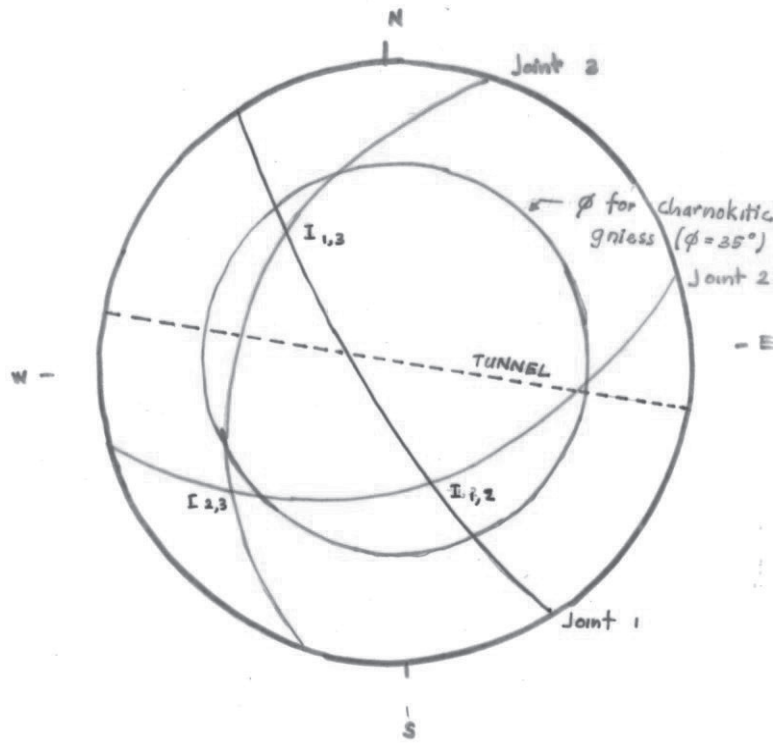

Rock Discontinuities with respect to Angle of Internal Friction for Route A Section 0-100 m

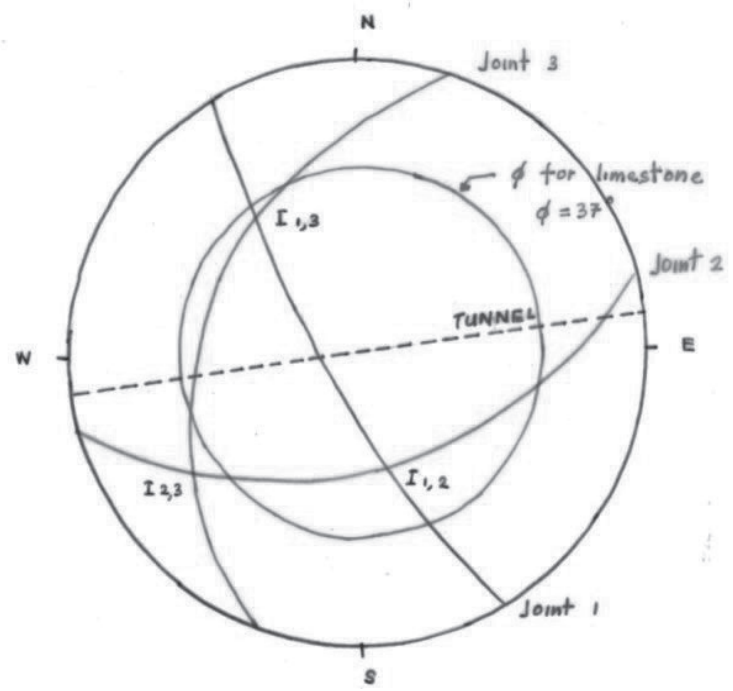

Figure 06 - Stereonet Plot of Great Circles of Rock Discontinuities with respect to Angle of Internal Friction - Route A Section 100-350m, Section $350-1500 \mathrm{~m}$ and Route B Section $0-40 \mathrm{~m}$ and Section $950-1500 \mathrm{~m}$
Results of the stereonet analysis are summarized in Figures 05, 06 and 07.

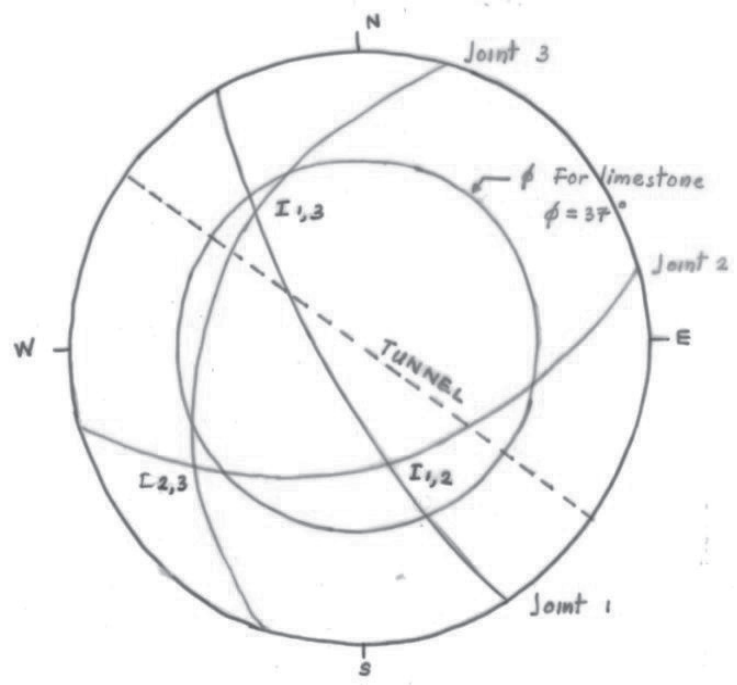

Figure 07 - Stereonet Plot of Great Circles of Rock Discontinuities with respect to Angle of Internal Friction - Route B Section 40 - 300 m

Table 05 - Orientation of Discontinuities

\begin{tabular}{ccc}
\hline Joint & Strike & Dip \\
\hline 1 & N 40 W & SW 70 \\
2 & N 55E & SE 50 \\
3 & N 30E & NW 50 \\
\hline
\end{tabular}

3.6 Cost Analysis for Tunnel Route Alternatives

Based on the engineering geological assessment, the applicable excavation and tunnelling methods were identified.

Considering the outcome, the excavation and supporting cost per meter run of the two alternatives were estimated and summarized in Tables 06 and 07. 
Table 06 - Total Cost Distribution for Each Section of Tunnel Route A

\begin{tabular}{|c|c|c|c|c|c|c|c|}
\hline $\begin{array}{c}\text { Chainage } \\
\text { (m) }\end{array}$ & $0-8$ & $8-100$ & $100-220$ & $220-323$ & $323-400$ & $400-508$ & $508-1200$ \\
\hline $\begin{array}{l}\text { Cost for } \\
\text { Crown }\end{array}$ & $810,000.00$ & $21,938,422.22$ & $28,615,333.33$ & $29,649,694.44$ & $27,542,985.56$ & $32,422,800.00$ & $87,441,888.89$ \\
\hline $\begin{array}{l}\text { Cost for } \\
\text { Wall }\end{array}$ & $972,000.00$ & $11,178,000.00$ & $25,156,000.00$ & $21,592,233.33$ & $23,869,486.67$ & $26,852,400.00$ & $84,078,000.00$ \\
\hline $\begin{array}{l}\text { Cost for } \\
\text { Invert }\end{array}$ & $1,311,040.00$ & $15,076,960.00$ & $19,665,600.00$ & $16,879,640.00$ & $12,618,760.00$ & $17,699,040.00$ & $113,404,960.00$ \\
\hline $\begin{array}{l}\text { Total Cost } \\
\text { (LKR) }\end{array}$ & $3,093,040.00$ & $48,193,382.22$ & $73,436,933.33$ & $68,121,567.78$ & $64,031,232.22$ & $76,974,240.00$ & $284,924,848.89$ \\
\hline
\end{tabular}

Calculation of per meter cost for tunnel route $A$
Mobilization of contractor
(LKR)
$=300,000,000.00$
Temporary Arrangements
(LKR)
$=170,000,000.00$
Total Cost for $1200 \mathrm{~m}$ (LKR)
$=1,088,775,244.44$
Cost per $1 \mathrm{~m}$ (LKR)( According to 2007 rates)
$=907,312.70$
To find the value in year 2015,
$\mathbf{F V}=\mathbf{P V} \times(1+\mathbf{r})^{\mathrm{y}}$
Where;
$\mathrm{FV}$ is the future value $=$ Value in year 2015
$\mathrm{PV}$ is the present value $=$ Value in year $2007=$ Rs. 907,312.70
$\mathrm{r}$ is the rate of interest $=4 \%$ (Obtained from Annual Report of
Central Bank)
$\mathrm{y}$ is the period in years $=8$

Hence,
$\mathrm{FV}=\underline{\underline{1,241,720.09}}(\mathrm{LKR})$
Say $1,245,000.00($ LKR)

Table 07 - Total Cost Distribution for Each Section of Tunnel Route B

\begin{tabular}{lcccccc}
\hline Chainage $(\mathbf{m})$ & $\mathbf{0 - 4 0}$ & $\mathbf{4 0 - 1 5 0}$ & $\mathbf{1 5 0 - 2 0 0}$ & $\mathbf{2 0 0 - 2 7 5}$ & $\mathbf{2 7 5 - 8 6 0}$ & $\mathbf{8 6 0 - 1 5 0 0}$ \\
\hline Cost for & $11,514,444.44$ & $31,664,722.22$ & $14,393,055.56$ & $17,859,436.27$ & & $80,871,111.11$ \\
Crown & & & & & \\
Cost for Wall & $8,041,176.47$ & $22,113,235.29$ & $10,051,470.59$ & $15,077,205.88$ & $263,250,000.00$ & $77,760,000.00$ \\
Cost for Invert & $6,461,600.00$ & $17,769,400.00$ & $8,077,000.00$ & $12,115,500.00$ & & $103,385,600.00$ \\
$\begin{array}{l}\text { Total Cost } \\
\text { (LKR) }\end{array}$ & $\mathbf{2 6 , 0 1 7 , 2 2 0 . 9 2}$ & $\mathbf{7 1 , 5 4 7 , 3 5 7 . 5 2}$ & $\mathbf{3 2 , 5 2 1 , 5 2 6 . 1 4}$ & $\mathbf{4 5 , 0 5 2 , 1 4 2 . 1 6}$ & $\mathbf{3 0 8 , 3 0 2 , 1 4 2 . 1 6}$ & $\mathbf{2 6 2 , 0 1 6 , 7 1 1 . 1 1}$ \\
\hline
\end{tabular}

Calculation of per meter cost for tunnel route B

Mobilization of contractor*

Temporary Arrangements*

* For tunnel

Total Cost for $1500 \mathrm{~m}$ (LKR)

Cost per 1m (LKR)(According to rates in year 2007)

To find the value in year 2015,

$\begin{array}{rr}= & 180,000,000.00 \\ = & 150,000,000.00 \\ = & 1,075,457,100.00 \\ = & 716,971.40\end{array}$

$\mathbf{F V}=\mathbf{P V} \times(\mathbf{1}+\mathbf{r})^{\mathrm{y}}$

Where;

$\mathrm{FV}$ is the future value $=$ Value in year 2015

$\mathrm{PV}$ is the present value $=$ Value in year $2007=716,971.40$

$\mathrm{r}$ is the rate of interest $=4 \%$ (Obtained from Annual Report of

Central Bank)

$\mathrm{y}$ is the period in years $=8$

$\mathrm{FV}=\underline{\underline{981,224.87}}(\mathrm{LKR})$ Say 985,000.00 (LKR) 


\section{Applying AHP}

\subsection{Selection of Optimal Tunnel Route}

As described in section 2.3, the ten criteria were prioritized using the results obtained from the questionnaire survey. Figure 08 depicts the priority chart of criterion. Then the pair-wise incorporated in the assessment of best tunnelling method. The priority chart for the criterion is presented in Figure 09.

The tunnel route was divided into following three sections based on the engineering geological characteristics;

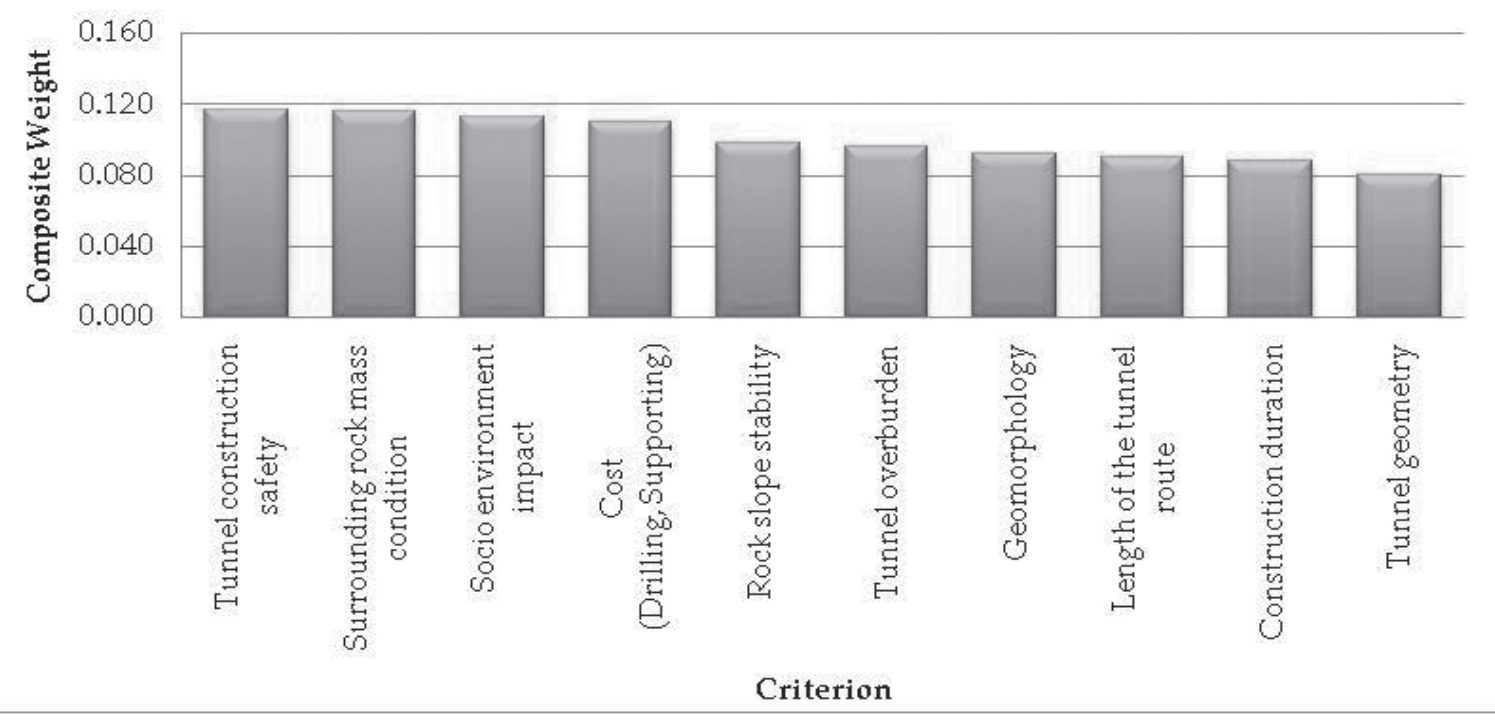

Figure 08 - Criterion Priority Chart for Optimal Tunnel Route Selection

Table 08 - Overall Composite Weights for Tunnel Route Alternatives

\begin{tabular}{|c|c|c|c|c|c|c|c|c|c|c|c|}
\hline Criterion & 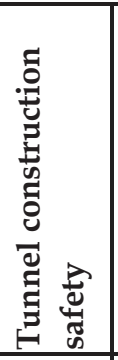 & 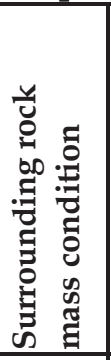 & 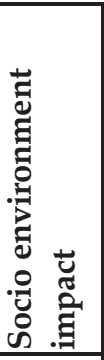 & 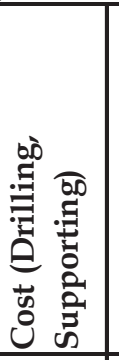 & 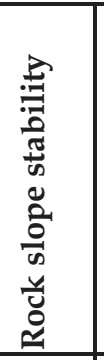 & 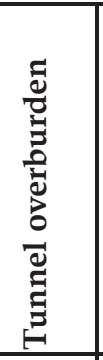 & 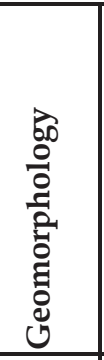 & 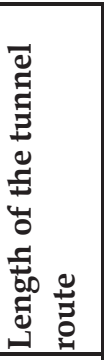 & 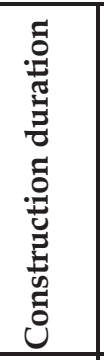 & 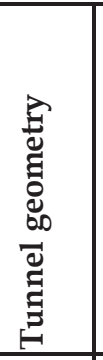 & $\begin{array}{c}\text { Composite } \\
\text { weight }\end{array}$ \\
\hline Weight & 0.117 & 0.116 & 0.113 & 0.110 & 0.098 & 0.096 & 0.092 & 0.090 & 0.088 & 0.080 & - \\
\hline A & 0.167 & 0.750 & 0.111 & 0.250 & 0.500 & 0.750 & 0.500 & 0.750 & 0.750 & 0.500 & 0.487 \\
\hline B & 0.833 & 0.250 & 0.889 & 0.750 & 0.500 & 0.250 & 0.500 & 0.250 & 0.250 & 0.500 & 0.513 \\
\hline
\end{tabular}

comparison matrices were developed and the weights of each alternative against each criterion were calculated as described in section 2.3 under specimen calculation. The overall composite weights are listed in Table 08 .

From the overall composite ranking of the two routes, it can be concluded that the tunnel route $\mathrm{B}$, having a rating of $0.513(51.3 \%)$ is preferred over route $\mathrm{A}$.

\subsection{Selection of Suitable Tunnelling Method} During the analysis under section 4.1, it was revealed that the tunnel route $B$ is the most appropriate option. Hence, from there onwards, characteristic features of tunnel route B were
1. Section I- From chainage 0 to $200 \mathrm{~m}$

2. Section II -From chainage 200 to $940 \mathrm{~m}$

3. Section III -From chainage 940 to $1500 \mathrm{~m}$

Each section was analysed against the applicability of each technique according to specific engineering geological characteristic assessment using AHP technique. The overall composite weights for each section are listed in Tables 09 to 11.

As depicted in Tables 09 to 11, the results of AHP reveals that, NATM is preferred for section A and B, and Drill and Blast method is preferred for section $\mathrm{C}$. 


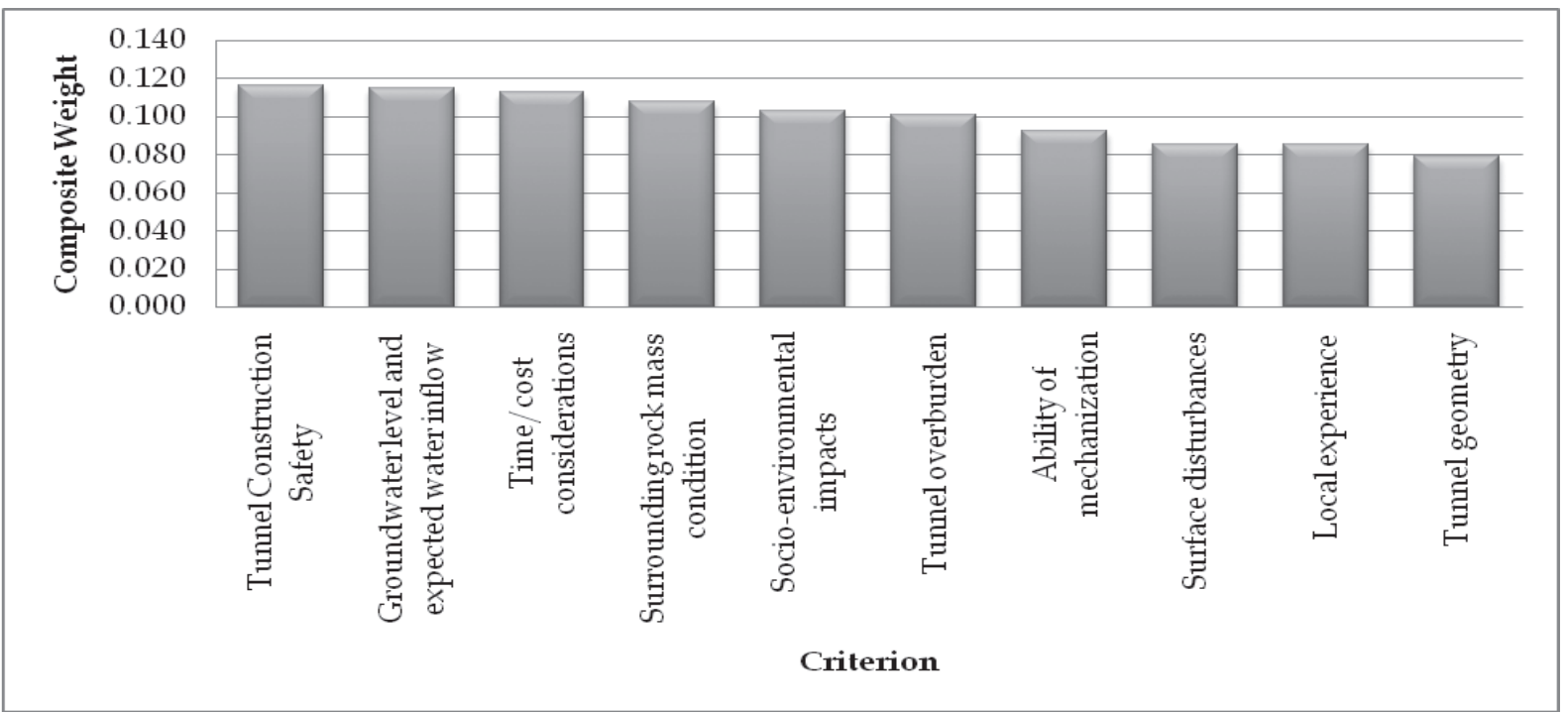

Figure 09 - Criterion Priority Chart for Tunnelling Method Selection

Table 09 - Overall Composite Weights for Section I

\begin{tabular}{|c|c|c|c|c|c|c|c|c|c|c|c|}
\hline Criterion & 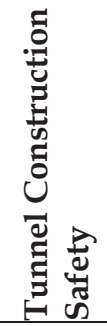 & 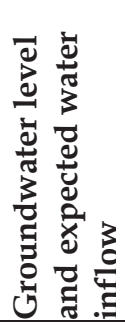 & 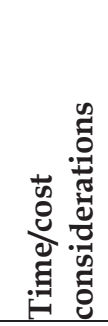 & 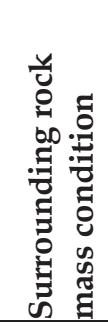 & 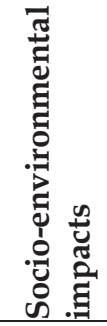 & 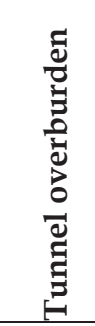 & 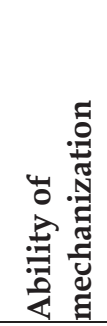 & 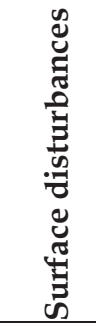 & 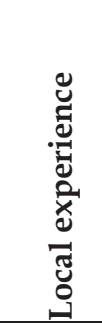 & 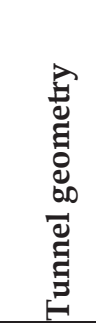 & $\begin{array}{c}\text { Overall } \\
\text { Composite } \\
\text { weight }\end{array}$ \\
\hline Weight & 0.117 & 0.115 & 0.113 & 0.108 & 0.103 & 0.101 & 0.093 & 0.086 & 0.086 & 0.079 & - \\
\hline D \& B & 0.106 & 0.140 & 0.260 & 0.260 & 0.286 & 0.260 & 0.333 & 0.283 & 0.600 & 0.106 & 0.257 \\
\hline$C \& C$ & 0.633 & 0.574 & 0.633 & 0.106 & 0.140 & 0.106 & 0.333 & 0.074 & 0.200 & 0.633 & 0.353 \\
\hline NATM & 0.260 & 0.286 & 0.106 & 0.633 & 0.574 & 0.633 & 0.333 & 0.643 & 0.200 & 0.260 & 0.390 \\
\hline
\end{tabular}

Table 10 - Overall Composite Weights for Section II

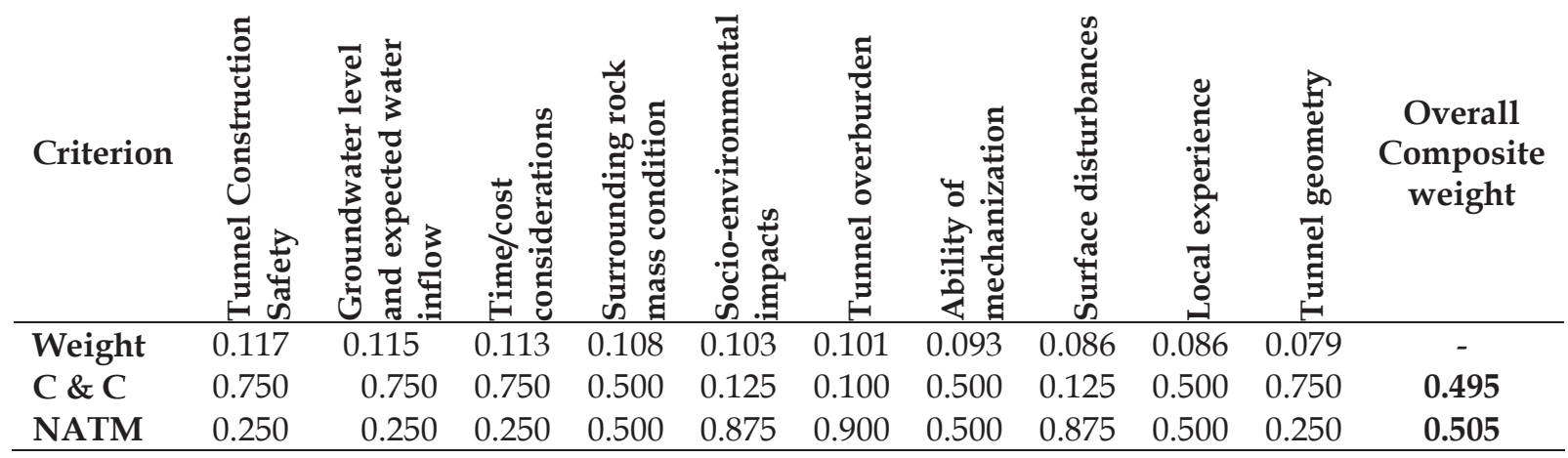

Table 11 - Overall Composite Weights for Section III

\begin{tabular}{|c|c|c|c|c|c|c|c|c|c|c|c|}
\hline Criterion & 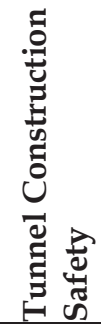 & 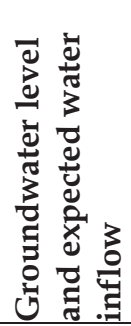 & 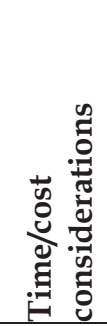 & 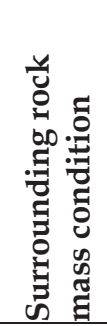 & 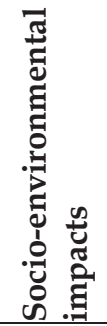 & 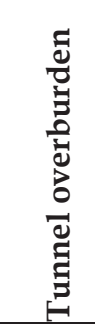 & 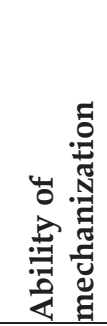 & 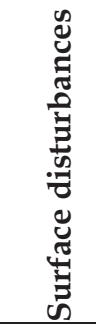 & 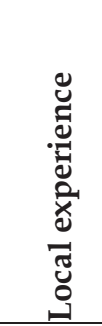 & 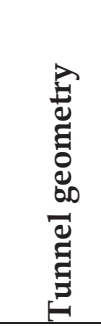 & $\begin{array}{c}\text { Overall } \\
\text { Composite } \\
\text { weight }\end{array}$ \\
\hline Weight & 0.117 & 0.115 & 0.113 & 0.108 & 0.103 & 0.101 & 0.093 & 0.086 & 0.086 & 0.079 & - \\
\hline$D \& B$ & 0.250 & 0.875 & 0.833 & 0.750 & 0.167 & 0.250 & 0.500 & 0.750 & 0.125 & 0.500 & 0.507 \\
\hline NATM & 0.750 & 0.125 & 0.167 & 0.250 & 0.833 & 0.750 & 0.500 & 0.250 & 0.875 & 0.500 & 0.493 \\
\hline
\end{tabular}




\section{Conclusions and Recommendations}

\subsection{Conclusions}

The study was limited to the tunnel routes, A, chainage $0-1200 \mathrm{~m}$ and for route $B$, chainage 0 $1500 \mathrm{~m}$, from that point onwards, both the tunnel routes follow a common path.

According to the geological cross sectional profiles developed along tunnel routes, considered portion of the tunnel route A passes through charnokitic gneiss, marble and biotite gneiss and tunnel route B passes through charnokitic gneiss, silty sand and biotite gneiss. Top overburden part of the profile along both the routes are covered by rock blocks, boulders and soils of gravel silty clay and silty sand. The engineering geological assessment revealed that the surrounding rock masses of both tunnel routes belong to the poor rock class.

The overall RMR value of the tunnel route $A$ is greater than that of the tunnel route $B$ and overall $Q$ value of tunnel route $A$ is much greater than tunnel route $B$.

Both $R M R$ and $Q$ values of tunnel route $A$ is much closer to the fair rock class. Therefore, the quality of the surrounding rock mass of the tunnel route $\mathrm{A}$ is considerably preferable than that of tunnel route $B$.

From the performed stereonet analysis for the major joint sets of the area, the rock wedge failures are possible along both tunnel routes.

The cost analysis revealed that tunnel route $\mathrm{B}$ is cost effective than tunnel route A. Per meter cost difference between two tunnel routes is approximately $21 \%$.

For the considered conditions and criterion, the final result of the Analytical Hierarchy Process (AHP) for tunnel route selections revealed that the route $B$ is the most optimal tunnel route.

According to the AHP analysis performed for tunnelling technique selection for tunnel route $\mathrm{B}$, chainage 0 to $940 \mathrm{~m}$, tunnel excavation has to be carried out using NATM and chainage 900 to $1500 \mathrm{~m}$, the tunnel excavation has to be performed using Drill \& Blast method. Therefore it can be concluded that a combination of Drill \& Blast and New Austrian Tunnelling method should be applied for the tunnel route $B$.

\subsection{Recommendations}

From above analysis following recommendations can be made.

1. Route $B$ is the most suitable tunnel route to be applied for the considered tunnel section of Broadlands Hydropower Project.

2. Combination of Drill \& Blast method and New Austrian Tunnelling Method should be adopted in constructing the tunnel along route $B$.

3. RMR and $Q$ values should be further verified through an additional geotechnical investigation programme or during the tunnel driving stage and the appropriate supporting system should be decided accordingly.

\section{Acknowledgments}

Authors would like to express special gratitude to all the industrial experts for completing the questionnaire. Authors also like to thank profusely the Management of the Ceylon Electricity Board, and the Project Staff of the Ceylon Electricity Board and Central Engineering Consultancy Bureau of Broadlands Hydropower Project for their extended support and co-operation provided throughout this study.

\section{References}

1. Ataei, M., Jamshidi, M., Sereshki, F. and Jalali, S. M. E., "Mining method selection by AHP Approach". The Journal of The Southern African Institute of Mining and Metallurgy, vol. 54, 2008, pp 103-117.

2. Palmström, A. and Strömme, B. "Engineering Geology and Rock Engineering Applied in the Design of Norwegian Tunnels", The Conference on Tunnels for the Third Millennium. Prievidza Slovakia, Norway, 1996, pp 1-16.

3. Ahmed, N. G. and Asmael, N. M., "A GISAssisted Optimal Urban Route Selection Based on Multi Criteria Approach". The Iraqi Journal for Mechanical and Material Engineering, Special Issue (D), 2009, pp 556-567.

4. Triantaphyllou, E. and Maan, S. H., "Using the Analytic Hierarchy Process for Decision Making in Engineering Applications: Some Challenges", Inter'l journal of Industrial Engineering: Applications and Practice, Vol. 2, No 1, 1995, pp 3544. 
5. Zolfani, S. H., Rezaeiniya, N., Zavadskas, E. K., \& Turskis, Z., "Forest Roads Locating Based On AHP and Copras-G Methods: An Empirical Study Based On Iran", E M Ekon. Manag. 2011, 4, pp 6-20.

6. Japan International Corporation Agency, Study of Hydropower Optimization in Sri Lanka, Final Report, Vol. I main report. Sri Lanka: Ceylon Electricity Board, 2004.

7. Indian Bureau of Mines, Application of Rock Mechanics in Surface and Underground Mining, 2014, pp 34-51.
8. Using the Q- system - Rock Mass Classification and Support Design, Norwegian Geotechnical Institute, 2013, pp.10-40.

9. Hoek, E. and Bray, J.W., Rock Slope Engineering. $3^{\text {rd }}$ ed., Institution of Mining and Metallurgy, London, 2005, pp 37-81.

10. Maeda - Nishimatsu Joint Venture, Upper Kotmale Hydropower Project. Bid for Lot 02 Main Civil Works.

11. Saaty, T. L., "Decision making with the analytic hierarchy process" Int. J. Services Sciences, Vol. 1, No. 1, 2008, pp 83-98. 
Engineering Geological Assessment along Tunnel Route A

\begin{tabular}{|c|c|c|c|c|c|}
\hline \multirow{2}{*}{$\begin{array}{l}\text { Route } \\
\text { Section } \\
\text { (m) }\end{array}$} & \multirow[t]{2}{*}{ Engineering Geological Evaluation } & \multirow{2}{*}{$\begin{array}{c}\mathrm{Q} \\
\text { Value }\end{array}$} & \multirow{2}{*}{$\begin{array}{l}\text { RMR } \\
\text { Value }\end{array}$} & \multicolumn{2}{|c|}{$\begin{array}{l}\text { Surrounding Rock } \\
\text { Pattern according to }\end{array}$} \\
\hline & & & & Q & RMR \\
\hline $0-8$ & $\begin{array}{l}\text { Terrain is rock platform, bedrock is pale greenish } \\
\text { gray to gray color charnokitic gneiss, exposed, } \\
\text { attitude is } \mathrm{N} 10^{\circ} \mathrm{W} \text { and } \mathrm{SW} \angle 65^{\circ} \text {. The bedrock depth } \\
\text { on the cave top is } 12 \sim 32 \mathrm{~m} \text {. Tunnel route penetrates } \\
\text { the fracture zone } \mathrm{F} 1,1-2 \mathrm{~m} \text { wide, attitude is } \mathrm{N} 80^{\circ} \mathrm{W} \\
\text { and NE } \angle 70^{\circ} \text {. From the stereo net analysis based on } \\
\text { three major joint sets in this region, surrounding rock } \\
\text { is said to be unstable and may generate unstable } \\
\text { blocks and wedges. According to obtained RMR and } \\
\mathrm{Q} \text { values, the surrounding rock type is "Fair". }\end{array}$ & 4.75 & 44 & Fair & Fair \\
\hline $8-100$ & $\begin{array}{l}\text { This section consist of gray } \sim \text { gray white marble rock, } \\
\text { measured attitude is N } 10^{\circ} \mathrm{W} \text { and } \mathrm{SW} \angle 65^{\circ} \text {, the } \\
\text { bedrock depth on the cave top is } 40 \sim 60 \mathrm{~m} \text {. From the } \\
\text { stereo net analysis based on three major joint sets in } \\
\text { this region, surrounding rock is said to be unstable } \\
\text { and may generate unstable blocks and wedges. } \\
\text { According to obtained RMR and Q values, the } \\
\text { surrounding rock type is "Fair". }\end{array}$ & 3.77 & 35 & Fair & Fair \\
\hline $100-220$ & $\begin{array}{l}\text { This section consist of gray } \sim \text { gray white marble rock, } \\
\text { measured attitude is } \mathrm{N} 10^{\circ} \mathrm{W} \text { and } \mathrm{SW} \angle 65^{\circ} \text {, the } \\
\text { bedrock depth on the cave top is } 12 \sim 15 \mathrm{~m} \text {. From the } \\
\text { stereo net analysis based on three major joint sets in } \\
\text { this region, surrounding rock is said to be unstable } \\
\text { and may generate unstable blocks and wedges. } \\
\text { According to obtained RMR and Q values, the } \\
\text { surrounding rock type is "Poor". }\end{array}$ & 1.43 & 35 & Poor & Poor \\
\hline $220-400$ & $\begin{array}{l}\text { In this section, tunnel route penetrates the fracture } \\
\text { zone F2, 60-90m wide, attitude is } N 20^{\circ} \mathrm{W} \text { and } \\
\mathrm{SW} \angle 35^{\circ} \text {, rock mass is broken. According to borehole } \\
\text { logs BB } 5 \text { and } \mathrm{ZK} 8 \text {, the fracture zone consist of } \\
\text { yellowish - brown mylonite. According to obtained } \\
\text { RMR and Q values, the surrounding rock type is } \\
\text { "exceptionally poor". }\end{array}$ & 0.002 & 17 & $\begin{array}{c}\text { Exceptionally } \\
\text { poor }\end{array}$ & $\begin{array}{l}\text { very } \\
\text { Poor }\end{array}$ \\
\hline $400-508$ & $\begin{array}{l}\text { In this section, tunnel route penetrates the fracture } \\
\text { zone } \mathrm{F} 2,60-90 \mathrm{~m} \text { wide, attitude is } \mathrm{N} 20^{\circ} \mathrm{W} \text { and } \\
\mathrm{SW} \angle 35^{\circ} \text {, rock mass is broken. According to borehole } \\
\text { logs } \mathrm{BB} 5 \text { and } \mathrm{ZK} 8 \text {, the fracture zone consist of } \\
\text { yellowish - brown mylonite. According to obtained } \\
\text { RMR and Q values, the surrounding rock type is } \\
\text { "extremely poor" and rock stability is extremely poor. }\end{array}$ & 0.07 & 17 & $\begin{array}{l}\text { Extremely } \\
\text { poor }\end{array}$ & $\begin{array}{l}\text { very } \\
\text { Poor }\end{array}$ \\
\hline
\end{tabular}




\begin{tabular}{|c|c|c|c|c|c|}
\hline \multirow{2}{*}{$\begin{array}{c}\text { Route } \\
\text { Section } \\
\text { (m) }\end{array}$} & \multirow{2}{*}{ Engineering Geological Evaluation } & \multirow{2}{*}{$\begin{array}{c}\mathrm{Q} \\
\text { Value }\end{array}$} & \multirow{2}{*}{$\begin{array}{l}\text { RMR } \\
\text { Value }\end{array}$} & \multicolumn{2}{|c|}{$\begin{array}{l}\text { Surrounding Rock } \\
\text { Pattern according to }\end{array}$} \\
\hline & & & & $Q$ & RMR \\
\hline $508-620$ & $\begin{array}{l}\text { Tunnel route pass through gray } \sim \text { dark gray biotite } \\
\text { gneiss, attitude is N } 10^{\circ} \mathrm{Wand} \mathrm{SW} \angle 40^{\circ} \text {. The bedrock } \\
\text { depth on the tunnel top is } 60 \sim 65 \mathrm{~m} \text {. Tunnel penetrates } \\
\text { the fracture F3, with mylonite as the major part, and } \\
\text { cataclasites as partial part, the attitude is } \mathrm{N} 15^{\circ} \mathrm{W} \text { and } \\
\mathrm{SW} \angle 45^{\circ} \text {, the rock mass is broken. From the stereo net } \\
\text { analysis based on three major joint sets in this region, } \\
\text { surrounding rock is said to be unstable and may } \\
\text { generate unstable blocks and wedges. According to } \\
\text { obtained RMR and Q values, the surrounding rock } \\
\text { type is "very poor". }\end{array}$ & 5.000 & 29 & Fair & $\begin{array}{l}\text { very } \\
\text { Poor }\end{array}$ \\
\hline $620-850$ & $\begin{array}{l}\text { As there is no borehole after } 620 \mathrm{~m} \text { chainage, it is } \\
\text { assumed the geological condition is same as } 508-620 \\
\text { section. Tunnel route pass through gray } \sim \text { dark gray } \\
\text { biotite gneiss, attitude is N } 10^{\circ} W a n d \mathrm{SW} \angle 40^{\circ} \text {. } \\
\text { According to stereo net analysis based on three major } \\
\text { joint sets in this region, surrounding rock is unstable } \\
\text { and may generate unstable blocks and wedges. }\end{array}$ & 5.000 & 46 & Fair & Poor \\
\hline $850-900$ & $\begin{array}{l}\text { As there is no borehole after } 620 \mathrm{~m} \text { chainage, it is } \\
\text { assumed the geological condition is same as } 508-620 \\
\text { section. But due to the fracture F } 4 \text {, the conditions may } \\
\text { be slight differ. Tunnel route pass through gray } \\
\text { dark gray biotite gneiss, attitude is N10 Wand SW } \angle \\
40^{\circ} \text {. From the stereo net analysis based on three major } \\
\text { joint sets in this region, surrounding rock is said to be } \\
\text { unstable and may generate unstable blocks and } \\
\text { wedges. According to obtained RMR and Q values, } \\
\text { the surrounding rock type is "Fair". }\end{array}$ & 5.000 & 41 & Fair & Fair \\
\hline $\begin{array}{l}900- \\
1200\end{array}$ & $\begin{array}{l}\text { As there is no borehole after } 620 \mathrm{~m} \text { chainage, it is } \\
\text { assumed the geological condition is same as } 508-620 \\
\text { section. Tunnel route pass through gray } \sim \text { dark gray } \\
\text { biotite gneiss, attitude is N } 10^{\circ} \text { Wand } \mathrm{SW} \angle 40^{\circ} \text {. From } \\
\text { the stereo net analysis based on three major joint sets } \\
\text { in this region, surrounding rock is said to be unstable } \\
\text { and may generate unstable blocks and wedges. } \\
\text { According to obtained RMR and Q values, the } \\
\text { surrounding rock type is "Fair". }\end{array}$ & 5.000 & 46 & Fair & Fair \\
\hline
\end{tabular}


Engineering Geological Assessment along Tunnel Route B

\begin{tabular}{|c|c|c|c|c|c|}
\hline \multirow{2}{*}{$\begin{array}{l}\text { Route } \\
\text { Section } \\
\text { (m) }\end{array}$} & \multirow{2}{*}{ Engineering Geological Evaluation } & \multirow{2}{*}{$\begin{array}{c}\mathrm{Q} \\
\text { Value }\end{array}$} & \multirow{2}{*}{$\begin{array}{c}\text { RMR } \\
\text { Value }\end{array}$} & \multicolumn{2}{|c|}{$\begin{array}{l}\text { Surrounding Rock } \\
\text { PatternAccording to }\end{array}$} \\
\hline & & & & $\mathbf{Q}$ & RMR \\
\hline $0-40$ & $\begin{array}{l}\text { Terrain is rock platform, bedrock is pale greenish } \\
\text { gray to gray color charnokitic gneiss, exposed, } \\
\text { attitude is } \mathrm{N} 15^{\circ} \mathrm{W} \text { and } \mathrm{SW} \angle 45^{\circ} \text {. The bedrock depth } \\
\text { on the tunnel top is } 06 \sim 10 \mathrm{~m} \text {. From the stereo net } \\
\text { analysis based on three major joint sets in this region, } \\
\text { surrounding rock is said to be unstable and may } \\
\text { generate unstable blocks and wedges. According to } \\
\text { obtained RMR and Q values, the surrounding rock } \\
\text { type is "very poor". }\end{array}$ & 0.89 & 41 & very poor & $\begin{array}{l}\text { Fair - } \\
\text { poor } \\
\text { margin }\end{array}$ \\
\hline $40-200$ & $\begin{array}{l}\text { Weakly weathered pale greenish gray to gray color } \\
\text { charnokitic gneiss, the attitude is } \mathrm{N} 10^{\circ} \mathrm{W} \text { and } \mathrm{SW} \angle \\
40^{\circ} \text {. The bedrock depth on the tunnel top is } 06 \sim 08 \mathrm{~m} \text {. } \\
\text { Tunnel route penetrates the fracture zone } \mathrm{F} 1,1-2 \mathrm{~m} \\
\text { wide, attitude is } \mathrm{N} 80^{\circ} \mathrm{W} \text { and NE } \angle 70^{\circ} \text {. From the stereo } \\
\text { net analysis based on three major joint sets in this } \\
\text { region, surrounding rock is said to be unstable and } \\
\text { may generate unstable blocks and wedges. According } \\
\text { to obtained RMR and Q values, the surrounding rock } \\
\text { type is "poor". }\end{array}$ & 0.54 & 42 & very poor & $\begin{array}{l}\text { Fair - } \\
\text { poor } \\
\text { margin }\end{array}$ \\
\hline $200-275$ & $\begin{array}{l}\text { Fully weathered to weakly weathered gray } \sim \text { gray } \\
\text { white marble, the attitude is } \mathrm{N} 8 \sim 17^{\circ} \mathrm{W} \text { and } \\
\mathrm{SW} \angle 38 \sim 48^{\circ} \text {, the structural face doesn't develop, rock } \\
\text { is broken. The bedrock depth on the tunnel top is } \\
06 \sim 08 \mathrm{~m} \text {. From the stereo net analysis based on three } \\
\text { major joint sets in this region, surrounding rock is } \\
\text { said to be unstable and may generate unstable blocks } \\
\text { and wedges. According to obtained RMR and Q } \\
\text { values, the surrounding rock type is "very poor". }\end{array}$ & 0.53 & 42 & very poor & $\begin{array}{l}\text { Fair - } \\
\text { poor } \\
\text { margin }\end{array}$ \\
\hline $275-750$ & $\begin{array}{l}\text { Tunnel route pass through } 5 \sim 22 \mathrm{~m} \text { thick silty sand } \\
\text { layer. According to CT3 and CT4 borehole logs, } \\
\text { Highly decomposed materials available at tunnel } \\
\text { depth. Rock mass classification is not applicable. }\end{array}$ & & & NA & \\
\hline $750-860$ & $\begin{array}{l}\text { In this section, tunnel route penetrates the fracture } \\
\text { zone F2, 60-90m wide, attitude is } \mathrm{N} 20^{\circ} \mathrm{W} \text { and } \\
\mathrm{SW} \angle 35^{\circ} \text {, rock mass is broken. According to borehole } \\
\text { logs BB } 5 \text { and ZK } 8 \text {, the fracture zone consist of } \\
\text { yellowish - brown mylonite. Only RMR value can be } \\
\text { obtained and accordingly, surrounding rock is "very } \\
\text { poor". }\end{array}$ & & 1 & & $\begin{array}{l}\text { Very } \\
\text { poor }\end{array}$ \\
\hline $\begin{array}{l}860- \\
1500\end{array}$ & $\begin{array}{l}\text { The tunnel penetrate through gray } \sim \text { dark gray biotite } \\
\text { gneiss, the attitude is } \mathrm{N} 25 \sim 65^{\circ} \mathrm{W} \text { and } \mathrm{SW} \angle 20 \sim 80^{\circ}, \\
\text { cave body penetrates fault } \mathrm{F} 3 \text { and } \mathrm{F} 4 \text { with width of } \\
8 \sim 10 \mathrm{~m} \text {. According to RMR and Q values, rock mass is } \\
\text { "fair" }\end{array}$ & 5.58 & 43 & Fair & Fair \\
\hline
\end{tabular}


$\underline{\text { Specimen Calculation for Rock Mass Classification }}$

\section{Route Option}

Chainage (m)

Referred Borehole No
A

$508-620$

BB6

Rock Mass Quality (Q)

\begin{tabular}{|l|c|c|}
\hline Parameter & Value & Rate \\
\hline Rock Quality Designation (RQD) & 100 & - \\
\hline Joint set number $\left(\mathrm{J}_{\mathrm{n}}\right)$ & - & 6 \\
\hline Joint roughness number $\left(\mathrm{J}_{\mathrm{r}}\right)$ & - & 3 \\
\hline Joint alteration number $\left(\mathrm{J}_{\mathrm{a}}\right)$ & - & 2 \\
\hline Joint water reduction factor $\left(\mathrm{J}_{\mathrm{w}}\right)$ & 56 & 0.2 \\
\hline Stress reduction factor $(\mathrm{SRF})$ & - & 1 \\
\hline Q value & \multicolumn{2}{|c|}{5.000} \\
\hline Rock Mass Quality & \multicolumn{2}{|c|}{ Fair } \\
\hline
\end{tabular}

\section{$\underline{\text { Rock Mass Rating (RMR) }}$}

\begin{tabular}{|l|c|c|}
\hline Parameter & Value & Rate \\
\hline $\begin{array}{l}\text { 1. Uniaxial compressive strength of } \\
\text { rock material. }\end{array}$ & $15-20$ & 2 \\
\hline 2. Rock Quality Designation (RQD). & 50 & 8 \\
\hline 3. Spacing of discontinuities. & & 10 \\
\hline 4. Condition of discontinuities. & & $11^{*}$ \\
\hline 5. Groundwater conditions. & & 0 \\
\hline 6. Orientation of discontinuities. & & -2 \\
\hline RMR & \multicolumn{2}{|c|}{29} \\
\hline Rock Type Poor \\
\hline
\end{tabular}

\begin{tabular}{|l|c|c|}
\hline 4. Condition of discontinuities. & Condition & Rate \\
\hline $\begin{array}{l}\text { Discontinuity length } \\
\text { (Persistence) }\end{array}$ & $>20$ & 0 \\
\hline Separation (Aperture)mm & $1-5 \mathrm{~mm}$ & 1 \\
\hline Roughness & $\begin{array}{c}\text { unsmooth- } \\
\text { smooth }\end{array}$ & 2 \\
\hline Infilling & Soft & 2 \\
\hline Weathering & unweathered & 6 \\
\hline Total rate & & $11^{*}$ \\
\hline
\end{tabular}


Guidelines for excavation and support of $10 \mathrm{~m}$ span rock tunnel in accordance with the RMR system (After Bieniawski 1989)

\begin{tabular}{|c|c|c|c|c|}
\hline $\begin{array}{l}\text { Rock mass } \\
\text { class }\end{array}$ & Excavation & $\begin{array}{l}\text { Rockbolts (20mm } \\
\text { diameter, fully } \\
\text { grouted) }\end{array}$ & Shotcrete & Steel sets \\
\hline $\begin{array}{l}\text { I - Very good } \\
\text { rock } \\
\text { RMR: } 81-100\end{array}$ & $\begin{array}{l}\text { Full face } \\
3 \mathrm{~m} \text { advance }\end{array}$ & \multicolumn{3}{|c|}{ Generally no support required except spot bolting. } \\
\hline $\begin{array}{l}\text { II- good rock } \\
\text { RMR: } 61-80\end{array}$ & $\begin{array}{l}\text { Full face } \\
1-1.5 \mathrm{~m} \text { advance. Complete } \\
\text { support } 20 \mathrm{~m} \text { from face }\end{array}$ & $\begin{array}{l}\text { Locally, bolts in } \\
\text { crown } 3 \mathrm{~m} \text { long, } \\
\text { spaced } 2.5 \mathrm{~m} \text { with } \\
\text { occasional wire } \\
\text { mesh. }\end{array}$ & $\begin{array}{l}50 \mathrm{mmin} \\
\text { crown where } \\
\text { required. }\end{array}$ & None \\
\hline $\begin{array}{l}\text { III - Fair rock } \\
\text { RMR: } 41-60\end{array}$ & $\begin{array}{l}\text { Top heading and bench } \\
1.5-3 \mathrm{~m} \text { advance in top } \\
\text { heading. } \\
\text { Commence support after } \\
\text { each blast. } \\
\text { Complete support } 10 \mathrm{~m} \text { from } \\
\text { face }\end{array}$ & $\begin{array}{l}\text { Systematic bolts } 4 \\
\mathrm{~m} \text { long spaced } \\
1.5-2 \mathrm{~m} \text { in crown } \\
\text { and walls with } \\
\text { wire mesh in } \\
\text { crown. }\end{array}$ & $\begin{array}{l}50-100 \mathrm{~mm} \text { in } \\
\text { crown and } \\
30 \mathrm{~mm} \text { in } \\
\text { sides. }\end{array}$ & None \\
\hline $\begin{array}{l}\text { IV- Poor rock } \\
\text { RMR: } 21-40\end{array}$ & $\begin{array}{l}\text { Top heading and bench } \\
1.0-1.5 \mathrm{~m} \text { advance in top } \\
\text { heading. Install support } \\
\text { concurrently with } \\
\text { excavation, } 10 \mathrm{~m} \text { from face }\end{array}$ & $\begin{array}{l}\text { Systematic bolts } \\
4-5 \mathrm{~m} \text { long, spaced } \\
1-1.5 \mathrm{~m} \text { in crown } \\
\text { and walls with } \\
\text { wire mesh. }\end{array}$ & $\begin{array}{l}100-150 \mathrm{~mm} \\
\text { in crown and } \\
100 \mathrm{~mm} \text { in } \\
\text { sides. }\end{array}$ & $\begin{array}{l}\text { Light to } \\
\text { medium ribs } \\
\text { spaced } 1.5 \mathrm{~m} \\
\text { where } \\
\text { required. }\end{array}$ \\
\hline $\begin{array}{l}\mathrm{V}-\quad \text { Very } \\
\text { Poor rock } \\
\text { RMR: } 21-40\end{array}$ & $\begin{array}{l}\text { Multiple drifts } 0.5-1.5 \mathrm{~m} \\
\text { advance in top heading. } \\
\text { Install support concurrently } \\
\text { with excavation. Shotcrete as } \\
\text { soon as possible after } \\
\text { blasting. }\end{array}$ & $\begin{array}{l}\text { Systematic bolts } \\
5-6 \mathrm{~m} \text { long, spaced } \\
1-1.5 \mathrm{~m} \text { in crown } \\
\text { and walls with } \\
\text { wire mesh. Bolt } \\
\text { invert. }\end{array}$ & $\begin{array}{l}\text { 150-200mm in } \\
\text { crown. } 150 \\
\text { mm in sides, } \\
\text { and } 50 \mathrm{~mm} \text { on } \\
\text { face. }\end{array}$ & $\begin{array}{l}\text { Medium to } \\
\text { heavy ribs } \\
\text { spaced } 0.75 \mathrm{~m} \\
\text { with steel } \\
\text { lagging and } \\
\text { forepoling if } \\
\text { required. Close } \\
\text { invert. }\end{array}$ \\
\hline
\end{tabular}

It should be noted that above table has not had a major revision since 1973. In many mining and civil engineering applications, steel fiber reinforced shotcrete may be considered in place of wire mesh and shotcrete. 
Estimated support categories based on the tunneling quality index Q (After Grimstad and Barton, 1993)

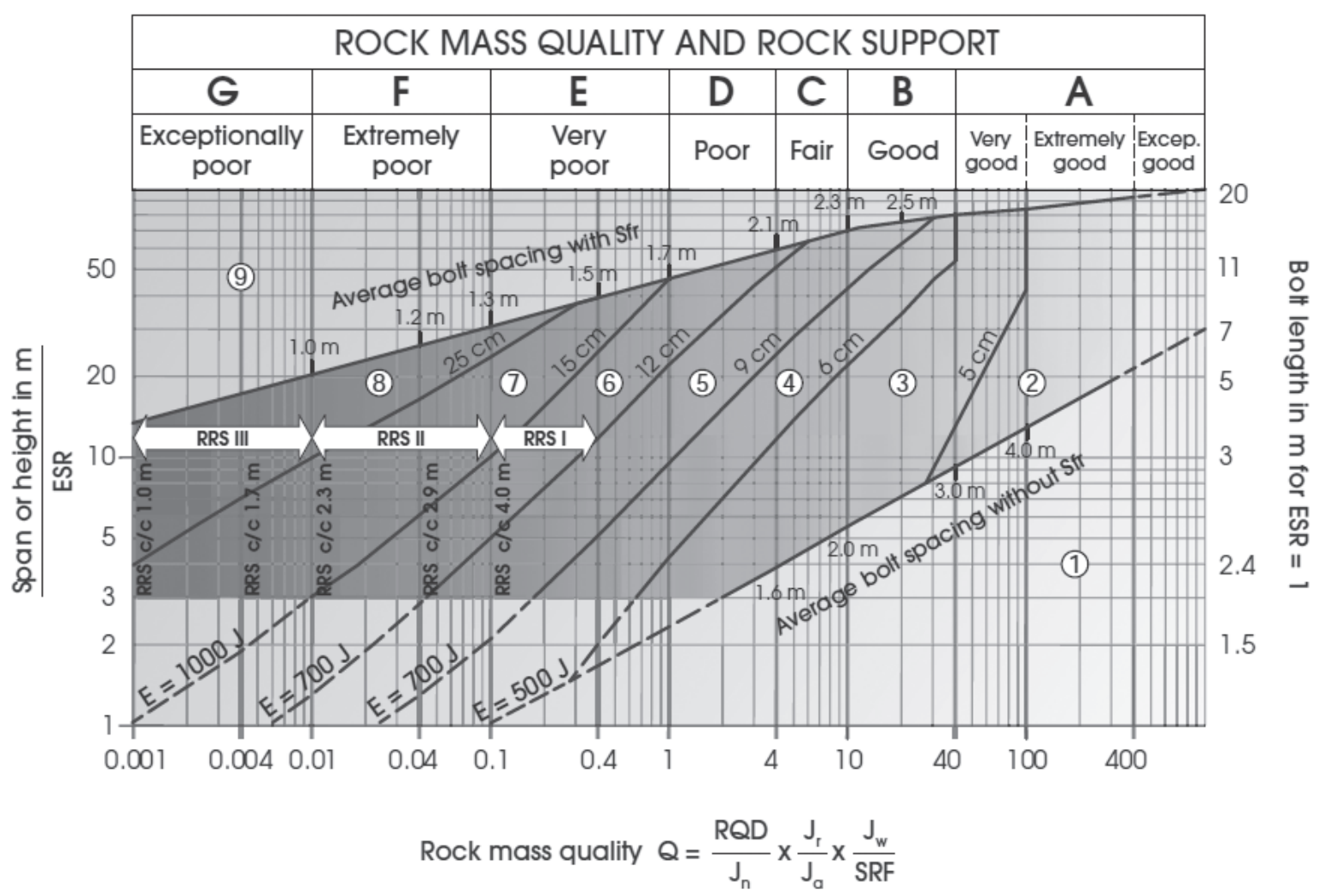

\section{Support categories}

(1) Unsupported or spot bolting

(2) Spot bolting, SB

(3) Systematic bolting, fibre reinforced sprayed concrete, 5-6 cm, B+Sfr

(4) Fibre reinforced spray $\ominus d$ concrete and bolting, 6-9 cm, Sfr (E500)+B

(5) Fibre reinforced sprayed concrete and bolting, 9-12 cm, Sfr (E700)+B

(6) Fibre reinforced sprayed concrete and bolting, $12-15 \mathrm{~cm}+$ reinforced ribs of sprayed concrete and bolting, Sfr (E700)+RRS I +B

(7) Fibre reinforced spray $\theta d$ concrete $>15 \mathrm{~cm}+$ reinforc $\ominus d$ ribs of spray $\theta d$ concrete and bolting, Sfr (E1000)+RRS II+B

(8) Cast concrete lining, CCA or Sfr (E1000)+RRS III+B

(9) Special өvaluation

Bolts spacing is mainly bas $\ominus \mathrm{d}$ on $\varnothing 20 \mathrm{~mm}$

$\mathrm{E}=$ Energy absorbtion in fibre reinforced sprayed concrete

ESR $=$ Excavation Support Ratio

Areas with dashed lines have no empirical data
RRS - spacing related to Q-value

Si30/6 Ø16- Ø20 (span 10m)

D40/6+2 Ø16-20 (span 20m)

Si35/6 Ø16-20 (span 5m)

(II) D45/6+2 ø16-20 (span 10m)

D55/6+4 Ø20 (span 20m)

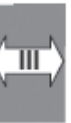

D40/6+4 Ø16-20 (span $5 \mathrm{~m}$ )

D55/6+4 ø20 (span 10 m)

D70/6+6 Ø20 (span 20 m)

Si30/6 = Single layer of 6 rebars,

$30 \mathrm{~cm}$ thickness of sprayed concrete

$\mathrm{D}=$ Double layer of rebars

$\varnothing 16=$ Rebar diameter is $16 \mathrm{~mm}$

c/c = RSS spacing, centr $\theta$ - centr $\Theta$ 


\title{
The Economic Comparison of Reservoir Type and Run of the River Type Hydropower Plants: A Case Study for Upper Kotmale Hydropower Plant
}

\author{
H.A.H. Amanda, W.A.D.S. Wijayapala, J.R. Lucas and W.J.L.S. Fernando
}

\begin{abstract}
Due to the severity of impacts predicted due to climate change issues, Greenhouse Gas (GHG) emissions need to be considered as a factor even for hydropower because of the identified emission possibilities associated with large reservoirs. Thus, when planning a large hydropower project at a selected location, it is important to decide on the type of power plant based on an economic comparison including environmental considerations. The existing 150MW, Talawakele run of the river type hydropower plant and the previously planned reservoir type Caledonia hydropower plant were selected for comparison in this study. Net greenhouse gas emissions from both projects were estimated based on several estimating techniques and for the economic comparison, the levelized cost of electricity of both projects were calculated. Results show that the unit cost of electricity generation from run of the river type is substantially lower (around LKR 4 per $\mathrm{kWh}$ ) than that of reservoir type. On the other hand, as Upper Kotmale is a peak-serving plant, a separate comparison was done considering the night peak operation. Results show a loss to the country (around LKR 2 billion per year) by energy reduction due to not implementing the reservoir type Caledonia hydropower plant. It is concluded that for future large hydropower developments in the world, a similar study should be carried out before deciding to downsize the reservoir. The study has further concluded that GHG emission considerations are not strong enough to discourage reservoir type new hydropower plant developments.
\end{abstract}

Keywords: Reservoir, run of river, hydropower, GHG emissions, levelized cost

\section{Introduction}

When planning a large hydropower project at a selected location, it is important to decide whether to construct a reservoir type or Run of the River (ROR) type based on an economic comparison including environmental and other considerations. There are environmental, social and economic impacts of hydropower projects which cannot be neglected, especially for large hydropower plants.

Owing to the severity of impacts predicted to be caused by climate change, GHG emissions need to be considered even for hydropower because of $\mathrm{CO}_{2}$ and $\mathrm{CH}_{4}$ emissions associated with large reservoirs. Disturbance to the ecosystem or loss of ecosystem is a negative impact to the environment including deforestation, impacts on fish owing to flow reduction and aesthetic effects on waterfalls. Reduced flow across waterfalls may cause reductions in tourism. Resettlement is a critical social impact caused by large hydropower projects. The economic advantage of reservoir type is the ability to store water and hence to be dispatched during both wet and dry seasons. Dry seasons affect the river flow of ROR type and hence the electricity generation.
The objectives of this research are to estimate the quantifiable advantages and disadvantages of reservoir type and ROR type hydropower generation, and to assess the economic impacts of converting reservoir type hydropower projects to ROR type hydropower projects at the design stage. In addition to costs related to power plants, costs related to environmental, social and economic impacts of hydropower are considered for project comparison.

Almost all the major hydropower potential has been developed in Sri Lanka by now. Out of the two existing large ROR type hydropower plants, Upper Kotmale Hydropower Project (UKHP) was taken as the case study for this

Eng. H.A.H. Amanda, BSc Eng (Hons) (Moratuwa), MSc (Moratuwa), AMIE(SL), AM(SLEMA), Electrical Engineer,

Lanka Energy Conservation (Pvt) Ltd.

Eng. W.D.A.S. Wijayapala, BSc Eng (Hons) (Moratuwa), MEng(Moratuwa), Int.PEng(SL), CEng, FIE(SL), Senior Lecturer, Department of Electrical Engineering, University of Moratuwa.

Eng. (Prof.) J.R. Lucas, BSc Eng (Hons) (Cey), MSc (Manch), PhD (Manch), FIEE, CEng, FIE(SL), MCS(SL), Emeritus Professor, Department of Electrical Engineering, University of Moratuwa.

Eng. W.J.L.S. Fernando, BSc Eng (Hons) (Moratuwa), MEng (Bangkok), CEng, FIESL, MIET (UK), ChairmanNational Engineering Research and Development Centre. 
research. However, as there are other countries with untapped potential of hydropower, this research outcomes will especially be important to them.

\section{Literature Review}

Worldwide research publications on comparison between reservoir type and ROR type hydropower plants were studied to identify the research gap.

A study [1] has been conducted focusing on the Amazonian regions of Bolivia, Brazil, Colombia, Ecuador and Peru, where a large untapped hydropower potential is available, qualitatively comparing the reservoir type and ROR type based on the climate change impacts. The study concludes that it will be necessary to invest in reservoirs to increase the margin of reserve and cope with climate change. The study also indicates the local, social and environmental impacts associated with the exploitation of hydropower. Another study [2] has also been conducted based on the climate change impacts of hydropower, focusing on Central and South American regions where $60 \%$ of the electricity demand is met through hydropower. Building new storage reservoirs is given in it as a potential adaptation measure.

A review [3] done for Yunnan in China, qualitatively compares small and large hydropower projects for their environmental implications and socio-economic consequences. A comparison [4] between large and small hydropower projects in Tibet, based on the $\mathrm{CO}_{2}$ equivalent states that small hydro performs better in terms of environmentally friendly development and low carbon energy than large hydro. In Tibet, large hydropower plants are essential to meet the large and growing electricity demand.

A study [5] from Western Himalayan region of India on environmental sustainability of ROR hydropower projects has been conducted. It presents a public perception cum data collection study on environmental impacts of small and large ROR hydropower projects. It concludes that every environmental impact of small hydropower is not "small" as compared to large hydropower and ignoring environmental impacts of small hydropower may not be a good practice in the Himalayan region.

A case study [6] has been conducted for Uma Oya hydropower project in Sri Lanka incorporating economic and socio- environmental considerations into project assessment but GHG emissions from reservoir has not been considered in that.

Findings in the last two decades indicate that hydropower reservoirs produce GHGs as $\mathrm{CO}_{2}$ and $\mathrm{CH}_{4}$, raising the question whether hydro power based generation is a clean and green electricity source [7],[8]. Most of the past world studies [9],[10],[11],[12],[13] focused on GHG emissions from hydropower reservoirs due to flooded organic matter decaying under water and the quantifications were based on long term field measurements. The results were summarized for tropical and non-tropical regions separately.

Latest research findings on methods of GHG emissions from hydropower and quantification of them were studied because it is an emerging study area at present. The study done by A.B. Hidrovo et al., "Accounting for GHG net reservoir emissions of hydropower in Ecuador"[8], presents a rough and holistic estimate of net annual GHG emissions from reservoirs in the absence of long term field measurements. It is difficult to estimate the costs related to all ecological impacts of hydropower projects and their research covered only deforestation.

\section{Case Study}

There are many reservoir type large hydropower projects in Sri Lanka [14] but only two large ROR type projects, namely Upper Kotmale Hydropower Project (UKHP) (150MW) and Kukule Ganga Hydropower Project $(70 \mathrm{MW})$ are in operation at present. These two were constructed during the recent past, compared to the time period in which the other reservoir type projects were implemented in Sri Lanka. Out of the above two, UKHP was selected for the case study in this research.

For UKHP, an earlier planned (1985-1987) Caledonia reservoir type project and the already implemented Talawakele ROR type project are taken for comparison. These two sites are located at Kotmale Oya in Nuwara Eliya District, Central Province, Sri Lanka. The distance between the two locations is about $10 \mathrm{~km}$. Table 1 gives the salient features of these two projects. The estimated cost of Caledonia reservoir project is given in 1986 prices. This price to be adjusted to 2014 prices for the economic comparison under this study and adjusted project cost is shown in Table 11. 
Table 1 - Project features

\begin{tabular}{|l|r|r|}
\hline \multicolumn{1}{|c|}{ Item } & $\begin{array}{r}\text { Caledonia } \\
\text { Reservoir } \\
{[\mathbf{1 5}]}\end{array}$ & $\begin{array}{c}\text { Talawakele } \\
\text { ROR }\end{array}$ \\
\hline Catchment $\left(\mathrm{km}^{2}\right)$ & 235.80 & 310.60 \\
\hline Dam type & $\begin{array}{r}\text { concrete } \\
\text { gravity }\end{array}$ & $\begin{array}{r}\text { concrete } \\
\text { gravity }\end{array}$ \\
\hline Dam height (m) & 70.00 & 34.00 \\
\hline $\begin{array}{l}\text { Gross storage } \\
\text { capacity (MCM) }\end{array}$ & 45.10 & 2.50 \\
\hline $\begin{array}{l}\text { Effective storage } \\
\text { capacity (MCM) }\end{array}$ & 30.00 & 0.80 \\
\hline $\begin{array}{l}\text { Reservoir/pond } \\
\left.\text { Area (km }{ }^{2}\right)\end{array}$ & 2.25 \\
\hline Rated head (m) & 614.00 & 473.00 \\
\hline $\begin{array}{l}\text { Maximum turbine } \\
\text { discharge (m } / \mathrm{s})\end{array}$ & 40.00 & 36.90 \\
\hline $\begin{array}{l}\text { Installed capacity } \\
\text { (MW) }\end{array}$ & 214.00 & 150.00 \\
\hline $\begin{array}{l}\text { Estimated Annual } \\
\text { Energy (GWh) }\end{array}$ & 664.00 & 409.00 \\
\hline $\begin{array}{l}\text { Project cost } \\
\text { (million LKR) }\end{array}$ & $1986)$ & $\begin{array}{r}53,040 \\
\text { (base year } \\
2014)\end{array}$ \\
\hline
\end{tabular}

The original proposal of Talawakele ROR had suggested to take tributary diversions to the main stream (Kotmale Oya) in order to get a larger catchment area. Accordingly, the annual energy generation was originally estimated as 512.00 GWh in the Environmental Study in 1995, but five waterfalls were to be impacted due to that proposal. Therefore, all the tributary diversions were cancelled. That resulted in the reduction of the annual energy to $409.00 \mathrm{GWh}$ in the implemented Talawakele ROR project.

\section{GHG Emissions from}

\section{Hydropower Projects}

In reservoirs/ponds, there are decomposed organic matter (flooded and upstream organic matter). These organic matters produce $\mathrm{CO}_{2}$ and $\mathrm{CH}_{4}$ which reach the water surface layer and release to the atmosphere by diffusion. $\mathrm{CH}_{4}$ is also released by bubbling. These bubbles are produced in the methanogenesis process. Less $\mathrm{CO}_{2}$ bubbles are also produced because $\mathrm{CO}_{2}$ has a higher solubility than $\mathrm{CH}_{4}$. GHG are again released to the atmosphere by degasification when the water passes through the spillways of the dam and turbines. This is due to the change of temperature, pressure and turbulence. GHG are also released to the atmosphere by diffusion in the downstream river. The previously generated turbulence helps the gases to be easily diffused to the air.
These emissions can be precisely determined by long term field measurements. In the absence of long term field measurements, a complete, rough and holistic estimate of net GHG emissions from hydropower projects per year $\left(E_{n}\right)$ can be obtained from the Equation 1[8].

$$
E_{n}=E_{e}+E_{r}+E_{t s d}+E_{c o m}
$$

Where,

$\mathrm{E}_{\mathrm{e}} \quad$ = GHG emissions due to the loss of ecosystem (pre-flooding)

$\mathrm{E}_{\mathrm{r}} \quad=\mathrm{GHG}$ emissions from reservoir

$\mathrm{E}_{\mathrm{tsd}}=\mathrm{GHG}$ emissions from turbine, spillway and downstream river (postflooding)

$\mathrm{E}_{\mathrm{com}}=\mathrm{GHG}$ emissions from construction, operation and maintenance

\subsection{Estimation of Emissions from Loss of} Ecosystem

The formula of photosynthesis and respiration [8], [16] was applied to estimate $E_{e}$. This is given in Equation 2.

$$
\begin{array}{rl}
\mathrm{CO}_{2}(264 g)+\mathrm{H}_{2} & \mathrm{O} \\
& \rightarrow 108 \mathrm{~g}) \\
& \left.\rightarrow \mathrm{C}_{6} \mathrm{H}_{12}\right) \mathrm{O}_{6}(180 \mathrm{~g})+\mathrm{O}(192 \mathrm{~g}) \\
& \rightarrow \text { Amylase }(162 \mathrm{~g})
\end{array}
$$

The particular element called amylase is related to growth of dry matter in a plant. Dry matter weight of a plant type can be obtained from its Net Primary Production (NPP) data [8]. Table 2 gives typical NPP values for tropical forest and cultivated land [17].

Table 2 - NPP values

\begin{tabular}{|l|r|}
\hline \multicolumn{1}{|c|}{ Land Type } & \multicolumn{1}{|c|}{ NPP } \\
& (dry matter $\mathbf{( g )} / \mathbf{m}^{2} /$ year) \\
\hline Tropical forest & $1,500.00$ \\
\hline Cultivated land & 650.00 \\
\hline
\end{tabular}

Table 3 gives the land use prior to inundation for the two selected projects.

Table 3 - Land use of the selected projects

\begin{tabular}{|l|r|r|r|r|}
\hline \multirow{2}{*}{ Land Use } & \multicolumn{2}{|c|}{$\begin{array}{c}\text { Caledonia } \\
\text { Reservoir }\end{array}$} & \multicolumn{2}{c|}{$\begin{array}{c}\text { Talawakele } \\
\text { ROR }\end{array}$} \\
\cline { 2 - 5 } & $\begin{array}{r}\text { Land } \\
\text { Type }\end{array}$ & $\begin{array}{r}\text { Area } \\
\text { (ha) }\end{array}$ & $\begin{array}{r}\text { Land } \\
\text { Type }\end{array}$ & $\begin{array}{r}\text { Area } \\
\text { (ha) }\end{array}$ \\
\hline $\begin{array}{l}\text { Dam site and } \\
\text { reservoir }\end{array}$ & Tea & 232.00 & Tea & 33.80 \\
\hline $\begin{array}{l}\text { Resettlement } \\
\text { area }\end{array}$ & Tea & 368.00 & Tea & 26.20 \\
\hline $\begin{array}{l}\text { Power house } \\
\text { and } \\
\text { switchyard }\end{array}$ & Tea & 15.00 & Forest & 14.20 \\
\hline
\end{tabular}

Based on the information in Table 2 and Table 3 , the loss of dry matter production, and hence the $\mathrm{CO}_{2}$ emissions per year of the two sites are 
estimated as follows. NPP of tea plantations was assumed to be that of the available cultivated land data in literature.

- Loss of dry matter production due to loss of tea plantations in Caledonia reservoir project $=650 \mathrm{gm}^{-2} \mathrm{yr}^{-1} \times(232+368+15) \times 10^{4} \mathrm{~m}^{2}$ $=3,997.50$ ton $/$ year

Hence, $\mathrm{E}_{\mathrm{e}}=1.63 \times 3,997.50$ ton $\mathrm{CO}_{2} /$ year $=6,515.93$ ton $\mathrm{CO}_{2} /$ year

- Loss of dry matter production due to loss of tea plantations and forest in Talawakele ROR project

$$
\begin{aligned}
= & 650 \mathrm{gm}^{-2} \mathrm{yr}^{1} \times(33.80+26.20) \times 10^{4} \mathrm{~m}^{2+} \\
& 1500 \mathrm{~g} \mathrm{~m}^{-2} \mathrm{yr}^{-1 \times}(14.20) \times 10^{4} \mathrm{~m}^{2} \\
= & 603.00 \mathrm{ton} / \text { year }
\end{aligned}
$$

$$
\text { Hence, } \mathrm{E}_{\mathrm{e}}=1.63 \times 603 \text { ton } \mathrm{CO}_{2} / \text { year }
$$$$
=982.89 \text { ton } \mathrm{CO}_{2} / \text { year }
$$

\subsection{Estimation of Emissions from Reservoir}

When land is inundated, decaying organic matter under water results in GHG emissions. This GHG emission was estimated using Equation 3 [8],[18].

$$
E_{r}=E_{f} \times A_{e}
$$

Where,

$$
\begin{array}{ll}
\mathrm{E}_{\mathrm{f}} & =\text { Mean reservoir emission factor } \\
\mathrm{A}_{\mathrm{e}} & =\text { Area of reservoir/pond }
\end{array}
$$

Following long term field measurements data, past studies [8],[19],[20] have shown that reservoir GHG emissions decay exponentially against reservoir life.

According to Zhang et al [18], it is almost impossible to determine this reservoir GHG emissions precisely in the absence of long term field measurements. Therefore, Zhang et al has applied directly a constant mean reservoir emission factor for the total reservoir lifetime. It showed that, boreal regions have a significantly lower GHG emissions than tropical regions. The boreal region is defined as the zone having a definite winter with snow, and a short summer, generally hot [21].

Sri Lanka is a tropical country. Long term field measurements has not been done in Sri Lanka yet. Therefore, constant mean $\mathrm{E}_{\mathrm{f}}$ of tropical regions was selected for this research for the total power plant lifetime as given in Equation 3.
Tropical $\mathrm{E}_{\mathrm{f}}=2,771.60 \mathrm{~g} \mathrm{CO}_{2} \mathrm{eq} \mathrm{m}^{-2} \mathrm{yr}^{-1}$ [18]

Table 4 - Reservoir/Pond areas

\begin{tabular}{|l|r|}
\hline \multicolumn{1}{|c|}{ Reservoir/Pond } & Area $\mathbf{( k m}^{2} \mathbf{)}$ \\
\hline Caledonia reservoir & 2.25 \\
\hline Talawakele pond & 0.25 \\
\hline
\end{tabular}

GHG emissions from reservoir/pond are estimated as follows based on Equation 3.

- $\mathrm{E}_{\mathrm{r}}$ from Caledonia reservoir

$=2,771.60 \mathrm{~g} \mathrm{CO}_{2}$-eq $\mathrm{m}^{-2} \mathrm{yr}^{-1} \times 2.25 \times 10^{6} \mathrm{~m}^{2}$

$=6,236.10$ ton $\mathrm{CO}_{2}$-eq/year

- $\quad \mathrm{E}_{\mathrm{r}}$ from Talawakele pond

$=2,771.60 \mathrm{~g} \mathrm{CO}_{2}$ eq m $\mathrm{m}^{-2} \mathrm{yr}^{-1} \times 0.25 \times 10^{6} \mathrm{~m}^{2}$

$=692.90$ ton $\mathrm{CO}_{2}$-eq/year

It should be noted that there may be differences between reservoir and ROR pond water behaviour. Water is always stored in the reservoir but in Talwakele pond, water is collected during the day time and used during the night peak hours. This may affect reservoir/pond GHG emission patterns, which have not been considered here.

4.3 Estimation of Emissions from Turbine, Spillway \& Downstream River

According to Hidrovo et al [8], out of the total direct GHG emissions ( $E_{\mathrm{r}}$ and $\mathrm{E}_{\mathrm{tsd}}$ ), 45\% would come from the reservoir and 55\% would come from turbine, spillway and downstream. Therefore, $\mathrm{E}_{\text {tsd }}$ was determined by Equation 4 [8].

$$
E_{t s d}=\frac{E_{r} \times 55}{45}
$$

- $\quad E_{\text {tsd }}$ from Caledonia project $=7,621.90$ ton $\mathrm{CO}_{2 \text {-eq/year }}$

- $\quad E_{\text {tsd }}$ from Talawakele ROR project $=846.88$ ton $\mathrm{CO}_{2}$-eq/year

\subsection{Estimation of Emissions from Construction, Operation \& Maintenance}

Life Cycle Impact Assessment (LCIA) is an accepted tool which allows to identify the potential environmental impacts associated with a product or service, throughout its entire lifespan [22]. A LCIA has been performed by Hidrovo et al [22] to determine $\mathrm{E}_{\mathrm{com}}$.

For this research, LCIAs performed for reservoir type and ROR type hydropower projects were studied from literature. $E_{c o m}$ 
values of the two case study projects were estimated accordingly.

\subsection{1 $E_{\text {com }}$ of Caledonia reservoir project}

Turconi et al [22] have critically reviewed case studies involving LCA of electricity generation from hydropower and found that $\mathrm{E}_{\mathrm{com}}$ was in the value range of $11-20 \mathrm{~kg} \mathrm{CO}$-eq/MWh for dam reservoirs. Zhang et al [23] used LCA to compare two reservoir hydropower schemes, one with a concrete gravity dam (CGD) and the other with an earth-core rockfill dam (ECRD). They have found that the CGD scheme had a higher $\mathrm{E}_{\mathrm{com}} \quad\left(11.11 \quad \mathrm{kgCO}_{2}\right.$-eq/MWh) than ECRD.

Caledonia reservoir also has a CGD and hence the best available approximation of $\mathrm{E}_{\mathrm{com}}$ for Caledonia was made as $11.00 \mathrm{kgCO}_{2}$-eq/ MWh.

Total $\mathrm{E}_{\mathrm{com}}=\left(11 \mathrm{kgCO}_{2}-\mathrm{eq} / \mathrm{MWh}\right) \times 664 \times 10^{3} \mathrm{MWh}$

$$
=7,304.00 \text { ton } \mathrm{CO}_{2} \text {-eq } / \text { year }
$$

\subsection{2 $\quad E_{\text {com }}$ of Talawakele ROR project}

H. Hondo [24] performed LCIA for ROR type hydropower projects and found that a ROR (plant life: 30 years, plant factor: $45 \%$ ) with small reservoir had $\mathrm{E}_{\mathrm{com}}$ value as $11.00 \mathrm{kgCO}_{2^{-}}$ eq/MWh. The variation of that with plant life and plant factor is given in Table 5 and Table 6 [24].

Table 5 - Effects of lifetimes on $\mathrm{E}_{\mathrm{com}}$

\begin{tabular}{|l|c|c|c|c|c|}
\hline $\begin{array}{l}\text { Lifetime } \\
\text { (years) }\end{array}$ & $\mathbf{1 0}$ & $\mathbf{2 0}$ & $\begin{array}{c}\mathbf{3 0} \\
\text { (ref) }\end{array}$ & $\mathbf{5 0}$ & $\mathbf{1 0 0}$ \\
\hline $\begin{array}{l}\mathrm{E}_{\mathrm{com}} \\
\left(\mathrm{kgCO} 2^{-}\right. \\
\text {eq/MWh } / \mathrm{MWh}^{-}\end{array}$ & 30.00 & 16.00 & 11.00 & 8.00 & 5.00 \\
\hline
\end{tabular}

Talawakele ROR has a plant life of 50 years. Therefore, $\mathrm{E}_{\mathrm{com}}$ value was approximated as 8.00 $\mathrm{kgCO}_{2}$-eq/MWh which was a reduction by 3.00 $\mathrm{kgCO}_{2}$-eq/MWh than the reference.

Table 6 - Effects of plant factors on $E_{c o m}$

\begin{tabular}{|l|c|c|c|c|c|}
\hline $\begin{array}{l}\text { Plant } \\
\text { factors (\%) }\end{array}$ & $\begin{array}{c}\mathbf{- 1 0} \\
\text { pts }\end{array}$ & $\begin{array}{c}\mathbf{- 5} \\
\text { pts }\end{array}$ & $\begin{array}{c}\mathbf{4 5} \\
\text { (ref) }\end{array}$ & $\begin{array}{c}+\mathbf{+ 5} \\
\text { pts }\end{array}$ & $\begin{array}{c}\mathbf{+ 1 0} \\
\text { pts }\end{array}$ \\
\hline $\begin{array}{l}\mathrm{kgCO}_{2^{-}} \\
\text {eq/ } \mathrm{MWh}\end{array}$ & 14.00 & 13.00 & 11.00 & 10.00 & 9.00 \\
\hline
\end{tabular}

Talawakele ROR has a plant factor of $30 \%$ and hence the values in Table 6 were plotted, as shown in Figure 1, to obtain $\mathrm{E}_{\mathrm{com}}$ at that plant factor.

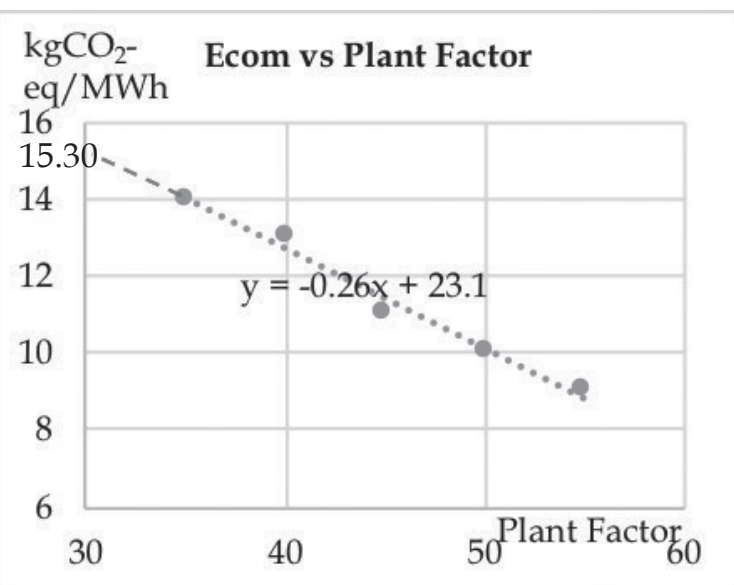

Figure 1 - Variation of $\mathrm{E}_{\text {com }}$ with plant factor in a ROR scheme with small reservoir

Extrapolation from Figure 1, gives the $E_{\text {com }}$ value for Talawakele $\mathrm{ROR}$ as $15.30 \mathrm{kgCO}_{2-}$ eq/ $\mathrm{MWh}$, which is an increase of $\mathrm{E}_{\text {com }}$ by 4.30 $\mathrm{kgCO}_{2}$-eq/MWh from the reference.

Based on these findings, the best available approximation of $\mathrm{E}_{\mathrm{com}}$ for Talawakele ROR project was made as $12.30 \mathrm{kgCO}_{2}$-eq/MWh, with 50 year plant life and 30\% plant factor.

$$
\begin{aligned}
\text { Total } \mathrm{E}_{\mathrm{com}}=\left(12.30 \mathrm{kgCO}_{2} \text {-eq } / \mathrm{MWh}\right) \times \\
\quad 409 \times 10^{3} \mathrm{MWh} \\
=5,030.70 \text { ton } \mathrm{CO}_{2} \text {-eq } / \text { year }
\end{aligned}
$$

\subsection{Total Emissions}

The net GHG emissions per year $E_{n}$ of Caledonia reservoir project and Talawakele ROR project were calculated and tabulated as in Table 7.

Table 7 - Net GHG emissions $\left(E_{n}\right)$ per year

\begin{tabular}{|l|c|r|}
\hline Parameter & $\begin{array}{c}\text { Caledonia } \\
\text { Project } \\
\text { (ton } \mathrm{CO}_{2-} \\
\text { eq/year) }\end{array}$ & $\begin{array}{c}\text { Talawakele } \\
\text { Project } \\
\text { (ton } \text { CO }_{2-} \\
\text { eq/year) }\end{array}$ \\
\hline $\mathrm{E}_{\mathrm{e}}$ & $6,515.93$ & 982.89 \\
\hline $\mathrm{E}_{\mathrm{r}}$ & $6,236.10$ & 692.90 \\
\hline $\mathrm{E}_{\mathrm{tsd}}$ & $7,621.90$ & 846.88 \\
\hline $\mathrm{E}_{\mathrm{com}}$ & $7,304.00$ & $5,030.70$ \\
\hline $\mathrm{E}_{\mathrm{n}}$ & $27,677.93$ & $7,553.37$ \\
\hline
\end{tabular}

The specific GHG emissions have also been calculated and tabulated in Table 8.

Table 8 - Specific GHG emission

\begin{tabular}{|l|c|c|c|}
\hline Project & $\begin{array}{c}\text { GWh/ } \\
\text { year }\end{array}$ & $\begin{array}{c}\text { Total } \\
\text { GHG } \\
\text { Emission } \\
\text { (ton CO } \\
\text { eq) } / \text { year }\end{array}$ & $\begin{array}{c}\text { Specific } \\
\text { GHG } \\
\text { Emission } \\
\text { (g CO }_{2-\text {-eq }} \\
/ \mathbf{k W h})\end{array}$ \\
\hline Caledonia & 664.00 & $27,677.93$ & 41.68 \\
\hline Talawakele & 409.00 & $7,553.37$ & 18.47 \\
\hline
\end{tabular}


It can be seen that even the GHG emissions from reservoir type hydropower projects are negligible compared to that of thermal power projects where specific GHG emissions are several hundred grams per kWh.

\section{Economic Comparison of Selected Hydropower Projects}

When making a decision on selecting a project among several project alternatives, technical feasibility and economic viability are two important criteria to be considered in engineering projects. The technical feasibilities of the two selected projects for comparison were ensured from their feasibility study reports. The decision making has been based on their economic viability.

\subsection{Levelized Cost of Electricity (LCOE)}

The economic comparison between the two types of plants was carried out by determining LCOE for each case.

$$
\text { LCOE }=\frac{\text { Total Lifetime costs }(\text { LKR) }}{\text { Total Lifetime Energy Output (kWh) }}
$$

The costs and benefits of the two types of plants were estimated as detailed below.

\subsection{Loan Details}

Financing for the UKHP was provided by Japan International Cooperation Agency (JICA) and the details are shown in Table 9.

Table 9 - Loan details of Talawakele ROR project

\begin{tabular}{|l|r|}
\hline \multicolumn{1}{|c|}{ Parameter } & \multicolumn{1}{|c|}{ Loan Details } \\
\hline Donor & $\begin{array}{r}\text { Japan International } \\
\text { Cooperation Agency (JICA) }\end{array}$ \\
\hline Agreement & 10 years \\
\hline Grace period & 30 years \\
\hline $\begin{array}{l}\text { Loan repayment } \\
\text { period }\end{array}$ & $0.93 \%$ on Japanese Yen (JPY) \\
\hline $\begin{array}{l}\text { Average interest } \\
\text { rate }\end{array}$ & $10.65 \%$ on Sri Lankan Rupees \\
\hline $\begin{array}{l}\text { Adjusted } \\
\text { interest rate }\end{array}$ & \\
\hline
\end{tabular}

\subsection{Project Cost and Loan Amount}

The project cost and the loan amount of the implemented Talawakele ROR project were calculated from the annual cost distribution data during the construction period. The result summary is given in Table 10.
Table 10 - Project cost and loan amount of Talawakele ROR project

\begin{tabular}{|l|r|}
\hline \multicolumn{1}{|c|}{ Parameter } & Value \\
\hline $\begin{array}{l}\text { Project cost (base year 2014) } \\
\text { (million LKR) }\end{array}$ & 53,040 \\
\hline $\begin{array}{l}\text { Original loan amount } \\
\text { (million LKR) }\end{array}$ & 47,251 \\
\hline $\begin{array}{l}\text { Loan as a percentage from project } \\
\text { cost (\%) }\end{array}$ & 89.00 \\
\hline $\begin{array}{l}\text { Adjusted loan amount at the end of } \\
\text { grace period (million LKR) }\end{array}$ & 51,834 \\
\hline
\end{tabular}

The project cost of Caledonia reservoir was taken from the Feasibility Study report [1]. The percentage of the original loan amount from the project cost was estimated as $89.00 \%$ to maintain the same conditions in both projects for comparison. The project cost summary for the Caledonia reservoir case is given in Table 11.

Table 11 - Project cost and loan amount of Caledonia reservoir project

\begin{tabular}{|l|c|}
\hline \multicolumn{1}{|c|}{ Parameter } & Value \\
\hline $\begin{array}{l}\text { Project cost (base year 1986) } \\
\text { (million LKR) }\end{array}$ & 7,920 \\
\hline $\begin{array}{l}\text { Adjusted project cost in 2014 } \\
\text { (million LKR) }\end{array}$ & 116,860 \\
\hline $\begin{array}{l}\text { Original loan amount } \\
\text { (million LKR) }\end{array}$ & 104,005 \\
\hline $\begin{array}{l}\text { Adjusted loan amount at the end of } \\
\text { grace period (million LKR) }\end{array}$ & 114,092 \\
\hline
\end{tabular}

For this study, loan repayment schedules of Talawakele ROR and Caledonia reservoir projects were considered during the 30 years of loan repayment period. The purpose was to obtain the cash outflow from capital repayments and interest payments (finance cost) in order to use for LCOE calculations.

\subsection{Plant Operation and Maintenance Cost}

Actual O\&M costs of the implemented Talawakele ROR type hydropower plant were obtained for year 2014, 2015 and 2016. The plant was commissioned on 14th July 2012 [25] and the O\&M cost could be exactly obtained since 2014. Those annual O\&M costs are given in Table 12.

Table 12 - O\&M cost of Talawakele ROR type hydropower plant

\begin{tabular}{|c|r|}
\hline Year & \multicolumn{2}{|c|}{$\begin{array}{c}\text { O\&M Cost } \\
\text { (million LKR) }\end{array}$} \\
\hline 2014 & 114.00 \\
\hline 2015 & 140.00 \\
\hline 2016 & 160.00 \\
\hline
\end{tabular}


These costs were extrapolated to obtain the O\&M costs for the rest of lifetime.

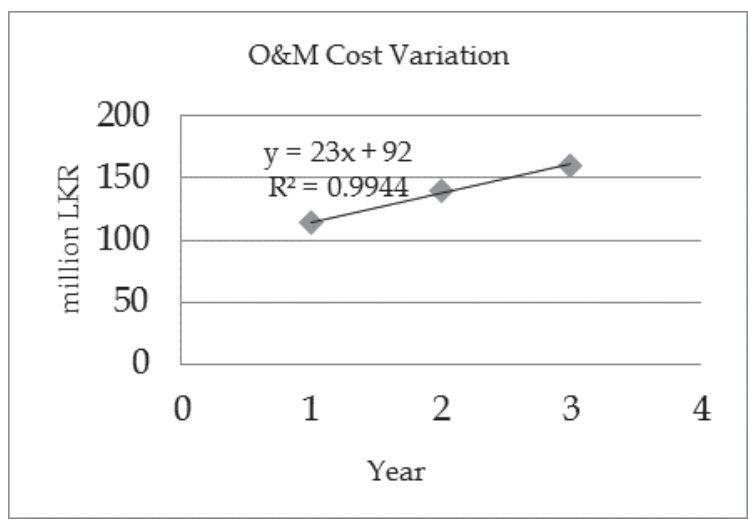

Figure 2 - O\&M cost variation of Talawakele ROR type hydropower plant

O\&M costs of Caledonia reservoir type hydropower plant were assumed to be proportionate to the plant capacity and hence the calculation of those were based on the O\&M costs of Talawakele ROR type hydropower plant. A sample calculation is given below.

O\&M cost of Caledonia reservoir plant in 2014 $($ million LKR $)=\underline{(23 \times 1+92)} \times 214 \mathrm{MW}$

$$
=164
$$

\subsection{Carbon Trading}

Carbon trading, which is also called Clean Development Mechanism (CDM), is an international market introduced by the Kyoto Protocol (KP) as a global strategy to combat global warming [26].

In this study, the average carbon trading price from August 2005 to November 2017 was calculated as Euro11.87/ton $\mathrm{CO}_{2}$. Average Euro to LKR exchange rate for the same period was calculated based on the CBSL data (1 Euro = 155.48 LKR). The converted average carbon trading price of $1,845.58 \mathrm{LKR} /$ ton $\mathrm{CO}_{2}$ was taken for the calculations in this study.

If UKHP was implemented under CDM, the GHG emission reduction compared to baseline emissions defined for CDM projects, could have been sold via carbon trading to earn an income. In this study, that was considered as benefits for both projects.

Grid Emission Factor (GEF) is a parameter to determine the baseline emissions for CDM projects in the renewable energy sector and waste heat/gas recovery sector. It refers to $\mathrm{CO}_{2}$ emission factor associated with each unit of electricity provided by an electricity system
[27]. The last updated GEF (in 2016) of Sri Lanka was taken for the calculations in this study.

GEF in Sri Lanka= 0.8199 ton $\mathrm{CO}_{2} / \mathrm{MWh}$ [28]

GHG emission reduction from Caledonia reservoir project compared to CDM baseline emissions

$$
\begin{aligned}
& =\left(0.8199 \times 664 \times 10^{3}-27,677.93\right) \text { ton } \mathrm{CO}_{2} / \text { year } \\
& =516,736 \text { ton } \mathrm{CO}_{2} / \text { year }
\end{aligned}
$$

Hence, CDM benefit (million LKR/year)= $(\mathrm{LKR} 1,845.58 /$ tonCO 2$) \times 516,736$ ton $\mathrm{CO}_{2} /$ year $=954$

GHG emission reduction from Talawakele ROR project compared to CDM baseline emissions $=\left(0.8199 \times 409 \times 10^{3}-7,553.37\right)$ ton $\mathrm{CO}_{2} /$ year $=327,786$ ton $\mathrm{CO}_{2} /$ year

Hence, CDM benefit (million LKR/year) $=\left(\right.$ LKR $1,845.58 /$ tonCO $\left._{2}\right) \times 327,786$ ton $\mathrm{CO}_{2}$ /year $=605$

\subsection{Levelized Cost of Electricity Calculation and Economic Comparison}

With above costs and benefits, two cash flows were prepared and Net Present Value (NPV) of total costs and NPV of energy were calculated considering the lifetime of the plants. The results are given in Table 13.

Table 13 - LCOE calculation summary

\begin{tabular}{|l|r|r|}
\hline \multicolumn{1}{|c|}{ Parameter } & $\begin{array}{c}\text { Caledonia } \\
\text { Reservoir } \\
\text { Project }\end{array}$ & $\begin{array}{c}\text { Talwakele } \\
\text { ROR } \\
\text { Project }\end{array}$ \\
\hline $\begin{array}{l}\text { NPV (Costs) } \\
\text { MLKR }\end{array}$ & 101,242 & 45,300 \\
\hline $\begin{array}{l}\text { NPV (Energy) } \\
\text { GWh }\end{array}$ & $6,583.44$ & $4,055.16$ \\
\hline $\begin{array}{l}\text { LCOE } \\
(\text { LKR/kWh) }\end{array}$ & $\mathbf{1 5 . 3 8}$ & $\mathbf{1 1 . 1 7}$ \\
\hline
\end{tabular}

From Table 13, it can be seen that the LCOE from Talawakele ROR project is substantially lower compared to the Caledonia reservoir type project.

\section{National Benefit}

Reservoirs can store water and hence the expected operation during peak demand hours can be obtained in both dry seasons and wet seasons of a year. In ROR, the flowing water is collected and stored during the day time in dry seasons in order to operate during the night peak. The expected peak operation may not always be possible because the stored water 
amount may not be sufficient to cover the entire peak period which is from 18.30 hours to 22.30 hours in Sri Lanka.

National benefits due to night peak operation of Caledonia reservoir and Talawakele ROR hydropower plants were calculated as detailed below.

$$
\begin{array}{lll}
\text { Installed capacity } & =214 \\
\text { Annual energy }(\mathrm{GWh}) & =664 \\
\mathrm{LCOE}(\mathrm{LKR} / \mathrm{kWh}) & =15.38 \\
\text { Night peak hours per day } & =4 \\
\text { Annual night peak generation }(\mathrm{GWh}) & =214 \times 4 \times 365 \times 90 \% \times 10^{-3} \\
= & 281.20
\end{array}
$$

Annual cost of generation during night peak $($ million LKR) $\quad=281.20 \times 15.38$

$$
=4,325
$$

Similarly, calculations were made for Talawakele ROR hydropower plant. Accordingly,

Annual night peak generation (GWh)

$$
=197.10
$$

Annual cost of generation during night peak (million LKR)

$$
\begin{aligned}
& =197.10 \times 11.17 \\
& =2,202
\end{aligned}
$$

Case 1: assuming rated operation of UKHP during the total night peak period of a year,

Annual financial loss or negative national benefit due to not having the Caledonia reservoir plant (million LKR)

$$
=4,325-2,202=2,123
$$

According to the results shown in Case 1, even though the Talwakele ROR hydropower plant operates in its full capacity (assuming every year is a wet year), there is an annual loss of LKR 2,123 million to the country by not having the Caledonia reservoir plant for peak serving.

Case 2: based on the actual night peak operation data of UKHP obtained from System Control Centre (SCC) of Ceylon Electricity Board (CEB), annual financial loss,

Table 14 - night peak generation of UKHP on actual basis and financial loss or negative national benefit by not having Caledonia reservoir plant

\begin{tabular}{|c|r|r|r|}
\hline Year & $\begin{array}{c}\text { Night Peak } \\
\text { Generation } \\
\text { (GWh) }\end{array}$ & $\begin{array}{c}\text { Annual Cost } \\
\text { of Night Peak } \\
\text { Generation } \\
\text { (million LKR) }\end{array}$ & $\begin{array}{c}\text { Annual } \\
\text { Financial } \\
\text { Loss } \\
\text { (million } \\
\text { LKR) }\end{array}$ \\
\hline 2014 & 172.00 & 1921 & 2,404 \\
\hline 2015 & 187.00 & 2089 & 2,236 \\
\hline 2016 & 146.00 & 1631 & 2,694 \\
\hline
\end{tabular}

SCC daily records the maximum output (MW) of UKHP during the night peak operation and the time it occurred. In this study, it was assumed that the plant operated with that output for the total night peak period in the respective days. Accordingly, the generated night peak energy were calculated for each year from 2014 to 2016 as shown in Table 14.

The results of Case 1 and Case 2 are summarized and given in Table 15.

Table 15 - Annual financial loss or negative national benefit based on rated and actual operation of Talawakele ROR project

\begin{tabular}{|l|r|r|}
\hline Year & \multicolumn{1}{|c|}{$\begin{array}{c}\text { Case 1: } \\
\text { Loss } \\
\text { (million LKR) }\end{array}$} & $\begin{array}{c}\text { Case 2: } \\
\text { Loss } \\
\text { (million LKR) }\end{array}$ \\
\hline 2014 & 2,123 & 2,404 \\
\hline 2015 & 2,123 & 2,236 \\
\hline 2016 & 2,123 & 2,694 \\
\hline
\end{tabular}

\section{Conclusions and \\ Recommendations}

It is concluded that GHG emission considerations are not strong enough to discourage reservoir type new hydropower plant developments.

According to the LCOE results, it can be concluded that the ROR type has the overall economic benefit in the case of UKHP, but if the project objective is solely to capture the maximum hydropower potential or peak serving, it can be concluded that the reservoir type has a better overall economic benefit to the country.

It is recommended that for similar future large hydropower developments, a detailed similar study to be carried out before taking the decision on reservoir construction for hydropower generation. A case by case study is recommended to be conducted because the environmental factors such as the impact of flooding, melting snow and ice, etc. vary from location to location. The methodology presented in this study can be followed for such studies with suitable modifications where necessary.

Although hydropower projects do not have
zero GHG emissions, as per this study, they
are much less compared to thermal power
plants. In view of grave need for limiting the
average global temperature increase to $2^{\circ} \mathrm{C}$ by
the end of this century and the GHG emission
reduction commitments made at the COP 21 at 
Paris, it is recommended that as many largescale hydropower projects as possible to be implemented capturing all possible hydropower potential in the world.

\section{Acknowledgement}

Authors wish to acknowledge the assistance given by the Project Director of UKHP to obtain data related to the existing Talawakele run of the river type hydropower project. At the same time, authors wish to acknowledge the Chief Engineer of Generation Planning Unit of Ceylon Electricity Board for giving access to obtain data related to the previously planned Caledonia reservoir type hydropower project. Authors also wish to acknowledge the assistance given by Deputy General Manager of the System Control Centre of Ceylon Electricity Board to obtain the past night peak operational data of UKHP. Finally, authors wish to acknowledge the Chief Engineer of UKHP for providing the actual operation and maintenance cost data of the existing UKHP.

\section{References}

1. Schaeffer, R. et al., "The vulnerable amazon: the impact of climate change on the untapped potential of hydropower systems," IEEE Power. Energy. Mag., vol. 11, no. 3, pp. 22-31, Apr. 2013.

2. Harrison, G. P. and Whittington, H. W., "Vulnerability of Hydropower Projects to Climate Change," Proc. IEE - Gener. Transm. Distrib., vol. 149, no. 3, pp. 249-255, May 2002.

3. Hennig, T. et al., "Review of Yunnan's Hydropower Development. Comparing small and large Hydropower Projects Regarding their Environmental Implications and Socio-economic Consequences," Renewable and Sustainable Energy Reviews, vol. 27, pp. 585-595, Nov. 2013.

4. Zhang J. et al., "Review on the Externalities of Hydropower: A Comparison between Large and Small Hydropower Projects in Tibet based on the $\mathrm{CO}_{2}$ Equivalent," Renewable and Sustainable Energy Reviews, vol. 50, pp. 176-185, Oct. 2013.

5. Kumar, D. and Katoch, S. S., "Environmental Sustainability of Run of the River Hydropower Projects: A Study from Western Himalayan Region of India," Renewable Energy, vol. 93, pp. 599-607, Aug. 2016.

6. Morimoto, R., "Incorporating SocioEnvironmental Considerations into Project Assessment Models using Multi-Criteria Analysis: A Case Study of Sri Lankan Hydropower Projects," Energy Policy, vol. 59, pp. 643-653, Aug. 2013.
7. Yang, L. et al., "Progress in the Studies on the Greenhouse Gas Emissions from Reservoirs," Acta Ecologica Sinica, vol. 34, no.4, pp. 204-212, Aug. 2014.

8. Hidrovo, A. B. et al., "Accounting for GHG net Reservoir Emissions of Hydropower in Ecuador," Renewable Energy, vol. 112, pp. 209221, Nov. 2017.

9. Descloux, S. et al., "Methane and Nitrous Oxide Annual Emissions from an Old Eutrophic Temperate Reservoir," Science of The Total Environment, vol. 598, pp. 959-972, Nov.2017.

10. Santos, M. A. D. et al., "Estimation of GHG Emissions by Hydroelectric Reservoirs: The Brazilian Case," Energy, vol.133, pp. 99-107, Aug. 2017.

11. Demarty, M. and Bastien, J., "GHG Emissions from Hydroelectric Reservoirs in Tropical and Equatorial Regions: Review of 20 years of $\mathrm{CH}_{4}$ Emission Measurements," vol.39, pp. 4197-4206, Jul. 2011.

12. Demlas, R., and Lacaux, C. G., "Emissions of Greenhouse Gases from the Tropical Hydroelectric Reservoir of Petit Saut (French Guiana) Compared with Emissions from Thermal Alternatives," Global biogeochemical Cycles, vol.15, no.4, pp. 993-1003, Dec. 2001.

13. Santos, M. A. D. et al., "Gross greenhouse gas fluxes from hydro-power reservoir compared to thermo-power plants," Energy Policy, vol.34, no.4, pp. 481-488, Mar. 2006.

14. [Online]. Available: https://www.ceb.lk/power-plants-list/en.

15. Japan International Corporation Agency, "Feasibility Study on Upper Kotmale Hydroelectric Power Development Project," Ceylon Electricity Board, Sri Lanka, Final Rep., Aug. 1987.

16. Guo, Z. et al., "Ecosystem Functions, services and their values - a case study in Xingshan County of China," Ecological Economics, vol. 38, no. 1, pp. 141-154, Jul. 2001.

17. World Heritage Encyclopedia. Primary Production[Online].Available:

http://www.ebooklibrary.org/Articles/Prim ary $\% 20$ production?\&Words=primary $\% 20$ pro duction.

18. Zhang, J. et al., "Review on the Externalities of Hydropower: A Comparison between Large and Small Hydropower Projects in Tibet based on the $\mathrm{CO}_{2}$ equivalent," Renewable and Sustainable Energy Reviews, vol. 50, pp. 176185, Oct. 2013. 
19. Demarty, M., and Bastien, J. "GHG Emissions from Hydroelectric Reservoirs in Tropical and Equatorial Regions: Review of 20 years of $\mathrm{CH}_{4}$ Emission Measurements," vol.39, pp. 4197-4206, Jul. 2011.

20. Demlas, R. and Lacaux, C. G. "Emissions of Greenhouse Gases from the Tropical Hydroelectric Reservoir of Petit Saut (French Guiana) Compared with Emissions from Thermal Alternatives," Global biogeochemical Cycles, vol.15, no.4, pp. 993-1003, Dec. 2001.

21. [Online]. Available:

https://definedterm.com/boreal_region.

22. Turconi, R. et al., "Life Cycle Assessment (LCA) of Electricity Generation Technologies: Overview, Comparability and Limitations," Renewable and Sustainable Energy Reviews, vol. 28, pp. 555-565, Dec. 2013.

23. Zhang, S. et al., "Carbon Footprint Analysis of two Different Types of Hydropower Schemes: Comparing Earth-Rockfill Dams and Concrete Gravity Dams using Hybrid Life Cycle Assessment," vol. 103, pp. 854-862, Sep. 2015.

24. Hondo, S. "Life Cycle GHG Emission Analysis of Power Generation Systems: Japanese Case," Energy, vol. 30, no. 11-12, pp. 2042-2056, Aug-Sep. 2005.

25. Ceylon Electricity Board. (2004). Upper Kotmale Hydropower Project [Online]. Available: http://www.ukhp.lk.

26. Batagoda, B. M. S., “Carbon Trading: A New International Business Opportunity in Sri Lanka," Economic Review, pp. 41-62, Jun/Jul. 2008.

27. Rocamora, A. and Amellina, A. (2017, November). IGES List of Grid Emission Factors [Online].Available:https://pub.iges.or.jp/pub /iges-list-grid-emission-factors.

28. [Online]. Available:

http://energybalance.axioon.com/. 